\title{
Kendi Paylarını İktisap Eden Anonim Şirketlerde Yedek Akçe Ayırma Uygulamasının Bir Değerlendirmesi
}

\author{
An Evaluation of Reserve Allocation Practice in Joint-Stock Companies \\ Acquiring Their Own Shares
}

\section{Raziye Aksu Özkan * iD}

\section{öz}

Anonim şirketin kendi paylarını iktisap etmesi birçok riski içinde barındırır. Bunlar şirket malvarlığının azalması, şirketin likiditesinin zayıflaması, bu durumun sermayenin iadesi yasağına aykırılık oluşturması ve satın alınan payların değerinin düşmesi sebebiyle şirketin zarara uğramasıdır. Bu sebeple, 6102 sayılı Türk Ticaret Kanunu madde 520/1 ile kendi paylarını iktisap eden şirketlere yedek akçe ayırma yükümlülüğü getirilerek, payın iktisap değeri kadar tutarı genel kurulun kullanmasını önlemek amaçlanmıştır. Bu çalışmada, anonim şirketin iktisap ettiği kendi payları için ayrılan yedek akçeler incelenmiş ve bunların ayrılmasının gerekli olup olmadığı değerlendirilmiştir. Buna göre, öncelikle şirketin kendi paylarını iktisap etmesi kavramı ele alınmıştır. Ardından iktisap edilen bu paylar için yedek akçe ayrılmasına ilişkin düzenlemeler incelenmiştir. Bu kısımda yedek akçe ayırmakla yükümlü şirkete ve ayrılacak yedek akçe tutarına yer verilmiştir. Daha sonra ayrılan yedek akçenin çözülmesine ve yedek akçe ayırma yükümlülüğüne aykırı davranışın hukuki sonuçlarına değinilmiştir. Son olarak şirketin iktisap ettiği payları için ayrılan yedek akçenin muhasebeleştirilmesi ele alınmıştır. Muhasebeleştirilmeye uygulanacak kuralların belirlenmesiyle görevli Kamu Gözetimi, Muhasebe ve Denetim Standartları Kurumunun düzenlemeleriyle şirketin iktisap ettiği payların raporlama şekli değiştirilmiştir. Buna göre, şirketin iktisap ettiği kendi payları, bilançonun aktifinde finansal bir varlık olarak raporlanamaz. Bunun yerine, bu paylar özkaynaktan düşülür. Bu değişiklik sebebiyle, şirketin iktisap ettiği kendi payları için yedek akçe ayırmasının gerekli olup olmadığı değerlendirilmiştir.

Anahtar Kelimeler Anonim Şirket, Kendi Payını İktisap, Şirketin İktisap Ettiği Kendi Payları İçin Ayrılan Yedek Akçe, Bilanço, Özkaynaktan İndirme Yöntemi

\section{ABSTRACT}

The acquisition of its own shares by a joint stock company involves many risks. These are the decrease in the company's assets, the weakening of the company's liquidity, this situation creates a violation of the prohibition of capital return and the loss of the company due to the decrease in the value of the purchased shares. For this reason, with the article 520/1 of the Turkish Commercial Code numbered 6102, companies that acquired their own shares were obliged to set aside reserves, and it was aimed to prevent the general assembly from using the amount equal to the acquisition value of the share. In this study, the reserves allocated for its own shares acquired by a joint-stock company are examined and whether it is necessary to separate them or not is evaluated. Accordingly, first of all, the concept of the company acquiring its own shares was discussed. Then, the regulations regarding the allocation of reserve for these acquired shares were examined. In this section, the company obliged to set aside the reserve and the amount of the reserve to be set aside are given. Later, the legal consequences of the act contrary to the resolution of the reserves and the obligation to set aside reserves were mentioned. Finally, the accounting of the reserves allocated for the shares acquired by the company was discussed. With the regulations of the Public Oversight, Accounting and Auditing Standards Authority in charge of determining the rules to be applied to accounting, the reporting method of the shares acquired by the company has been changed. Accordingly, the shares acquired by the company will not be reported as an asset in the balance sheet. Instead, if the company re-acquires its equity instruments, those instruments are deducted from equity. Due to this change, it has been evaluated whether it is necessary for the company to reserve for its own shares acquired.

Keywords: Joint-Stock Company, Acquisition of Own Shares, The Reserve Allocated for its Own Shares Acquired By Company, Balance Sheet, Equity Deducting Method

* Ar. Gör. Dr., Akdeniz Üniversitesi Hukuk Fakültesi Ticaret Hukuku Anabilim Dalı

Sorumlu Yazar/Correspondence Author: Raziye Aksu Özkan

E-posta/E-mail: raziyeaksu@akdeniz.edu.tr 


\section{Giriş}

6102 sayılı Türk Ticaret Kanunu (TTK) madde 379 ilâ 389'da, şirketin kendi paylarını iktisabı durumu düzenlenmiştir. Şirket, kendi paylarını çeşitli sebeplerle iktisap edebilir. Örneğin şirket bu yola pay sahiplerine nakit aktarmak, sinyal etkisi yaratmak ${ }^{1}$, şirketin finansal oranlarını iyileştirmek, kontrolünü rakiplere kaptırmamak ve payları belli pay sahiplerinde toplamak amacıyla veya kâr payı ödemesinin bir alternatifi olarak ${ }^{2}$ başvurabilir $^{3}$. Amacı her ne olursa olsun, ivazlı iktisaplarda payın iktisabı ile şirket malvarlığından pay bedeli ödemesi sebebiyle belirli bir tutar çıkar. Buna karşılık, pay edinimiyle şirket gerçek bir değer elde etmez ve bu paylar hâkimiyetinde bulunduğu sürece şirkete ortaksal veya mali bir hak kazandırmazlar (TTK m. 389). Dolayısıyla bu durum, şirket malvarlığını azaltır ${ }^{4}$. Keza kendi paylarının şirket tarafından iktisabı şirketin likiditesini de zayıflatacaktır ${ }^{5}$. Ayrıca bu durum, pay bedellerinin iktisap değerinden daha düşük bir fiyatla elden çıkarılması veya pay bedellerinin şirketin bağlı malvarlığından karşılanması durumunda sermayenin iadesi yasağına aykırılık oluşturur ${ }^{6}$. Bu sakıncalar sebebiyle şirketin kendi paylarını iktisabı kural

1 Şirketin paylarını geri alması, piyasadaki yatırımcılarda payların piyasada gerçek değerinin altında kaldığı algısı oluşturur. Bu algı (sinyal) da piyasaya olumlu yansır ve yatırımcıları pay almaya teşvik eder (Ahmet Gökgöz, 'Hisse Senedi Geri Alımı ve Muhasebesi' (2014) 7(2) Muhasebe ve Vergi Uygulamaları Dergisi 1, 4). Bu etki, kaldıraç etkisi yaratarak, payların değerlerinin artmasına neden olabilir. Böylelikle şirketin finansal durumu daha güçlenebilir. Bkz. Christian Lenz ve Andreas von Planta, 'Art. 659-659b' iç Heinrich Honsell, Nedim Peter Vogt ve Rolf Watter (edr), Basler Kommentar Obligationenrecht II Art. 530-964 OR (5. Bas1, Helbing Lichtenhahn 2016) Art. 659 N 11; Alihan Aydın, Anonim Ortaklığın Kendi Paylarını Edinmesi (Vedat 2008) 78; Ali Murat Sevi, 'Anonim Ortaklı̆̆ın Kendi Payını Devralması Üzerine Bir İnceleme' (2003) 22(1) Banka ve Ticaret Hukuku Dergisi 239, 246; Beşir Fatih Doğan, Der Erwerb eigener Aktien im deutschen und türkischen Recht im Hinblick auf europäisches Recht (Kovac 2004) 45-46.

2 Şirketlerin kendi paylarını satın almasıyla piyasadaki pay miktarı azalmakta ve pay başına düşen gelir artmaktadır. Bunun sonucunda da, payların piyasa fiyatı artmakta ve pay sahipleri nakit kâr payı yerine, sermaye kazancı elde etmektedirler. Bkz. Lukas Handschin (ed), Zürcher Kommentar Die Aktiengesellschaft, Allgemeine Bestimmungen, Art. 620-659b OR (2. Bası, Schulthess 2016) Art. 659 N 8; Reha Poroy, Ünal Tekinalp ve Ersin Çamoğlu, Ortaklklar Hukuku I (14. Bası, Vedat 2019) 656; Fatih Coşkun Ertaş ve Serdar Karaca, 'Kâr Dağıtımının İlânı ve Gerçekleşmesi Arasında Geçen Sürenin Firma Değerine Etkisi' (2010) (47) Muhasebe ve Finansman Dergisi 58, 64; Gökgöz (n 1$) 3$.

3 Gökgöz (n 1) 3-5; Mehmet Özdamar, Anonim Ortaklikların Kendi Paylarını İktisap Etmesi (TTK md. 329) (Yetkin Yayınları 2005) 57 vd; Aydın (n 1) 66 vd; Türk şirketin kendi paylarını edinmeye yönelten sebepleri, "ekonomik ve sosyal nedenler" ile "hukuksal nedenler" şeklinde ikiye ayırarak ele almıştır. Bkz. Ahmet Türk, Yeni Türk Ticaret Kanunu ve Sermaye Piyasası Mevzuatına Göre Anonim Ortaklğın Kendi Paylarını Edinmesi (Adalet 2016) 79-94.

4 Peter Forstmoser, Arthur Meier Hayoz and Peter Nobel, Schweizerisches Aktienrecht (2. Bası, Stämpfli 1996) $\$ 50 \mathrm{~N}$ 131; Hans Rudolf Trüeb, 'Art. 659 - 659a' iç Vito Roberto ve Hans Rudolf Trüeb (edr), Handkommentar zum Schweizer Privatrecht, Personengesellschaften und Aktiengesellschaft - Vergütungsverordnung, Art. 530-771 OR - VegüV (3. Bas1, Schulthess 2016) Art. 659 N 3; Hasan Pulaşl1, Şirketler Hukuku Şerhi C. 3 (3. Bası, Adalet 2018) 2376; Türk (n 3) 95; Aydın (n 1) 100; Oruç Hami Şener, Teorik ve Uygulamal Ortaklıklar Hukuku (4. Bası, Seçkin 2019) 395; Gül Okutan Nilsson, 'Anonim Şirketlerin Kendi Hisselerini İktisabı Bağlamında Finansal Yardım Yasağı', Anonim Şirketler ve Sermaye Piyasası Hukukunda Güncel Gelişmeler Türk - Alman Uluslararası Sempozyumu (İstanbul Borsası 2011), 90; Fikret Otlu, İsmail Bekçi ve Nilüfer Özlem Karataş, 'TTK’ya göre Anonim Şirketlerin Kendi Paylarını İktisap Etmesi ve Muhasebeleştirmesi' (2014) 4(1) Çankırı Karatekin Üniversitesi İktisadi ve İdari Bilimler Fakültesi Dergisi 283, 287.

5 Forstmoser, Meier Hayoz ve Nobel (n 4) $\$ 50$ N 133; Peter Böckli, Schweizer Aktienrecht (4. Bası, Schulthess 2009) $\$ 4$ N 197; Handschin (n 2) Art. 659 N 9; Hans Christoph Grigoleit ve Richard Rachlitz, iç Hans Christoph Grigoleit (ed), Aktiengesetz Kommentar (2. Bası, C.H. Beck 2020) § 71 N 10; Trüeb (n 4) Art. 659 N 4; Türk (n 3) 95; Okutan Nilsson (n 4) 90; Otlu, Bekçi ve Karataş (n 4) 287.

6 Forstmoser, Meier Hayoz ve Nobel (n 4) 50 N 132; Böckli (n 5) 44 N 222; Aydın (n 1) 99; Sevi (n 1) 241; Doğan (n 1) 7173; Okutan Nilsson, s. 90; Otlu, Bekçi ve Karataş, (n 4) 287. Şirketin kendi paylarını iktisap etmesinin, ekonomik olarak 
olarak yasaklanmış (TTK m. 379/1) ve istisnai hâllerde yapılabilecek iktisaba ilişkin hükümler emredici olarak düzenlenmiştir ${ }^{7}$. Bu düzenlemelerden biri de şirketin iktisap ettiği kendi payları için yedek akçe ayrılmasıdır (TTK m. 520/1). Bu yedek akçe ayrımı hem TTK’ye hem de 6362 sayılı Sermaye Piyasası Kanununa (SerPK) tâbi şirketler açısından zorunludur (SerPK m. 22; Geri Alınan Paylar Tebliği ${ }^{8}$ m. 20/2).

TTK m. 520/1'de düzenlenen yedek akçe, şirketin iktisap ettiği kendi payları için ayrılmaktadır. Bu payların muhasebeleştirme şekli, Kamu Gözetimi, Muhasebe ve Denetim Standartları Kurumunun (KGK) düzenlemeleri ile değiştirilmiştir. Buna göre, şirketin iktisap ettiği kendi payları artık şirketin bir varlığı olarak bilançonun aktifinde raporlanmayacaktır. Bu değişiklik, şirketin iktisap ettiği kendi payları için yedek akçe ayrılmasının gerekli olup olmadığını sorgulanmasına sebep olmuştur ${ }^{9}$.

Bu bağlamda, bu çalışmada anonim şirketin iktisap ettiği kendi payları için ayırdığı yedek akçe incelenecektir. $\mathrm{Bu}$ inceleme esnasında özellikle şirketin iktisap ettiği kendi paylarına ilişkin muhasebeleştirme şeklinin değişikliğinden sonra bunlar için ayrılan yedek akçenin gerekliliği değerlendirilecektir.

\section{I. Şirketin İktisap Ettiği Kendi Payları İçin Yedek Akçe Ayırması ve Ayrılan Yedek Akçenin Çözülmesi}

\section{A. Genel Olarak}

TTK m. 520/1 uyarınca şirket, iktisap ettiği kendi payları için iktisap değerlerini karşılayan tutarda yedek akçe ayırır. Şirketin iktisap ettiği kendi payları için ayırdığı yedek akçe, yedek akçelerin ayrılmalarını öngören veya karara bağlayan kaynak açısından kanuni yedek akçe grubunda yer alır ${ }^{10}$. Kanuni yedek akçeler, kanunun emredici hükümlerine göre ayrılması zorunlu olan yedek akçelerdir $^{11}$. Dolayısıyla kendi payını iktisap eden şirketin buna ilişkin yedek akçeyi ayırması

pay sahiplerine sermayenin geri ödenmesine eş değer olduğu hususunda bkz. Lukas Imark ve Lorenz Lipp, 'Art. 671671a' iç Vito Riberto ve Hans Rudolf Trüeb (edr), Handkommentar zum Schweizer Privatrecht, Personengesellschaften und Aktiengesellschaft - Vergütungsverordnung, Art. 530-771 OR - VegüV (3. Bası, Schulthess 2016) Art. 671a N 1; Şener (n 4) 395 .

7 Ünal Tekinalp, Sermaye Ortaklıklarının Yeni Hukuku (5. Bası, Vedat 2020) 108.

8 Geri Alınan Paylar Tebliği (II-22.1), RG 03.01.2014/28871.

9 İnceleme açısından bkz. II. Şirketin İktisap Ettiği Kendi Paylarının ve Bunun İçin Ayrılan Yedek Akçenin Muhasebeleştirilmesi.

10 Bu ayırım açısından yedek akçeleri "kanuni, esas sözleşmesel ve genel kurul kararı ile ayrılan yedek akçeler" şeklinde üçe ayrılır. Bkz. Poroy R, Tekinalp Ü ve Çamoğlu E, Ortaklıklar Hukuku II (14. Bası, Vedat 2019) 324-325; Mehmet Bahtiyar, Ortaklıklar Hukuku (14. Bası, Beta 2020) 300; Şener (n 4) 493; Pulaşlı (n 4) 2369; Karayalçın yedek akçeleri kanuni ve ihtiyari yedek akçe olarak ikiye ayırmaktadır. İhtiyari yedek akçe, statü hükümlerine göre veya genel kurul kararı ile ayrılan yedek akçelerdir. Bkz. Yaşar Karayalçın, Muhasebe Hukuku (2. Bası, Banka ve Ticaret Hukuku Araştırma Enstitüsü 1988) 114. İsviçre Hukuku’nda aynı ayrım için bkz. Forstmoser, Meier Hayoz ve Nobel (n 4) §50 N 7 ve devamı; Markus R. Neuhaus ve Patrick Balkanyi, 'Art. 671-671a' iç Heinrich Honsell, Nedim Peter Vogt ve Rolf Watter (edr), Basler Kommentar Obligationenrecht II Art. 530-964 OR (5. Bası, Helbing Lichtenhahn 2016) Art. 671 N 4a; Imark ve Lipp (n 6) Art. 671 N 1.

11 Poroy, Tekinalp ve Çamoğlu, Ortaklıklar Hukuku II (n 10) 324; Güzin Üçışık ve Aydın Çelik, Anonim Ortaklıkta Finansal 
zorunludur. Keza şirketin kendi paylarına ilişkin yedek akçeler, esas sözleşme veya genel kurul kararı ile ortadan kaldırılamaz ve sınırlandırılamazlar ${ }^{12}$.

\section{B. Düzenlemenin Amacı}

Şirketin kendi paylarını iktisabıyla şirket varlığı azalmakta ve şirket bedelini ödediği paylardan ekonomik anlamda faydalanamamaktadır ${ }^{13}$. Özellikle de payların değerinden çok düşük bir bedelle elden çıkarılması veya payların elden çıkarılmaksızın şirketin iflas ederek tasfiye sürecine girmesi gibi durumlarda, paylar için harcanan bedelin kısmen veya tamamen karşılı̆̆ da elde edilememektedir ${ }^{14}$. Dolayısıyla şirketin kendi paylarını iktisap etmesi, şirketin zarara uğrama riskini de içinde barındırmaktadır. Bu sebeple, şirketin iktisap ettiği kendi payları için yedek akçe ayrılması yükümlülüğü ile iktisap bedeli kadar şirket malvarlığının koruma altına alınması amaçlanmıştır ${ }^{15}$. Nitekim TTK m. 520/1 uyarınca şirketin kendi payları için ayırdığı yedek akçeler, anılan paylar devredilmedikçe veya yok edilmedikçe çözülemeyecektir. Böylece şirketin kendi paylarını iktisap için harcadığı tutar kadar varlığın, genel kurul tarafından kullanılması ${ }^{16}$ ve özellikle bunun pay sahiplerine dağıtılması engellenecektir ${ }^{17}$. Başka bir deyişle, bağlı yedek akçelere dâhil olan bu fon, payların değerinin düşmesi hâlinde ortaya çıkan zararın telafisi için bir tampon işlevi görmekte ve esas sermayenin karşılıksız kalmasını önlemektedir ${ }^{18}$. Bu sayede, geri alım nedeniyle döner değerleri azalmış olan ve/veya borcu artmış olan şirketin kâr olarak dağıtacağı tutar azaltılarak nakit pozisyonunun daha fazla kötüleşmemesi sağlanacaktır ${ }^{19}$.

Tablolar Yedek Akçeler ve Kâr Dağıtımı (On İki Levha 2018) 222; Pulaşlı (n 4) 2372; Bahtiyar (n 10) 300; Veysi Naci Tanış, Genel Muhasebe Ilkeler ve Uygulamalar (9. Bası, Karahan 2016) 280; Neuhaus ve Balkanyi (n 10) Art. 671 N 9; Imark ve Lipp (n 6) Art. 671 N 5. Bu sebeple Karayalçın kanuni yedek akçeleri, mecburi yedek akçe olarak da adlandırmaktadır. Bkz. Karayalçın (n 10) 114.

12 Poroy, Tekinalp ve Çamoğlu, Ortaklıklar II (n 10) 324.

13 Özge Ayan, 'Anonim Şirketin Genel Kuru Kararı ile Kendi Paylarını İktisap Etmesi veya Rehin Almasının Koşulları' (2013) XVII(1-2) Gazi Üniversitesi Hukuk Fakültesi Dergisi 185, 192; Türk (n 3) 96; Aydın (n 1) 99.

14 Forstmoser, Meier Hayoz ve Nobel (n 4) $\$ 50$ N 131; Böckli (n 5) $\$ 4$ N 197-199; Trüeb (n 4) Art. 659 N 5; Türk (n 3) 9596; Özdamar (n 3) 75-76; Aydın (n 1) 109-110; Ayan (n 13) 195; Doğan (n 1) 71-73. Kriz dönemlerinde payların değersiz olduğu yönünde bkz. Grigoleit ve Rachlitz (n 5) § 71 N 10.

15 Bu sebeple öğretide, kendi payları için yedek akçe ayrılması yükümlülüğünün öngörülmesi sermayenin korunması ilkesine dayandırılmaktadır [Bkz. Neuhaus ve Balkanyi (n 10) Art. 671a N 2; Ali Murat Sevi, Anonim Ortaklikta Payın Devri (4. Bası, Seçkin 2018) 87]. Bu ilke öğretide malvarlığının korunması ilkesi şeklinde de adlandırılmaktadır. Buna karşılık, Türk, bunlar yerine, "bağlı malvarlığının korunması ilkesi” ifadesinin kullanılması gerektiğini ileri sürmektedir. Zira TTK’nin bazı hükümleri, bilançonun aktifinde bulunan tüm değerleri değil, sadece sermaye ile şirketin üzerinde serbestçe tasarruf edemeyeceği yedek akçelerin karşılığını oluşturan varlıkları korumaktadır. Bu ilke yerine malvarlığının korunması ilkesi, kavramı olduğundan daha geniş; sermayenin korunması ilkesi ise daha dar ifade etmektedir. Bkz. Türk (n 3) 108

16 Imark ve Lipp (n 6) Art. 671a N 2.

17 Lukas Handschin, 'Eigene Aktien im Konzern' (2013) (8) Der Schweizer Treuhänder 485, 485; Trüeb (n 4) Art. 659a N 12; Böckli (n 5) \$8 N 323; Gökçen Turan, Anonim Ortaklıkların Kendi Paylarını İktisabının Genel Esasları (Yetkin 2018) 42; Ali İhsan Karacan ve Esra Erişir Karacan, Halka Açık Şirketlerin Kendi Paylarını Geri Alımı (Legal 2015) 159.

18 Türk (n 3) 98.

19 Karacan ve Erişir Karacan (n 17) 159. 


\section{C. Şirketin İktisap Ettiği Kendi Payları Iç̧in Yedek Akçe Ayırması}

\section{I. Şirketin Kendi Paylarını Iktisap Etmesi}

TTK m. 520/1 uyarınca yedek akçe ayrılması zorunluluğu, şirketin kendi paylarını iktisabı ile doğar ${ }^{20}$. Şirket, kendi paylarını hem ivazlı hem de ivazsız olarak iktisap edebilir (TTK m. 379 ve 383). Bununla birlikte, yedek akçe ayırma yükümlülüğü ivazlı iktisap durumunda söz konusu olacaktır ${ }^{21}$. Nitekim hükümde açıkça payların iktisap değerlerini karşılayan tutarda yedek akçe ayrılacağı öngörülmüştür (TTK m. 520/1). Başka bir deyişle, kendi payları için yedek akçe oluşturma yükümlülüğü, ancak riski şirketin kendisine ait olmak üzere payların geri alınması durumunda geçerlidir ${ }^{22}$. TTK $\mathrm{m}$. 520/1'de, şirketin iktisap ettiği payları için yedek akçe ayrılacağı düzenlenmiş; ancak bu iktisabın amaçları açısından herhangi bir ayrıma gidilmemiştir. Bununla birlikte, öğretide bir görüş bu yedek akçenin, payların TTK m. 379/1 ve 2 uyarınca iktisabı hâlinde değil, paylar ne suretle olursa olsun anonim şirket tarafından satın alınması durumunda ayrılacağı yönündedir ${ }^{23}$. Diğer bir görüşe göre, paylar sermayenin azaltılması amacıyla alınıyorsa yedek akçe ayrılmasına gerek yoktur ${ }^{24}$. Zira bunlar cari veya sabit varlıklar değildir. Bu paylar artık TTK m. 379 anlamı dâhilinde şirketin gerçek payı olarak nitelendirilemez. İmha amacıyla satın alınan paylar, satın alma fiyatı üzerinden özkaynaktan düşülmelidir. Kanaatimizce de şirket kendi paylarını genel kurulun sermaye azaltımı kararı üzerine satın alıyorsa, yedek akçe ayrılmasına gerek yoktur. Zira yedek akçe ayrılması ile iktisap bedeli kadar şirket malvarlığının koruma altına alınması amaçlanmıştır. Oysa edinilen paylar sermaye azaltımı ile yok edileceği için, yedek akçe ayırmanın amacı kalmayacaktır. Keza TTK m. 520/1 uyarınca söz konusu yedek akçenin çözülebileceği hâllerden birinin, iktisap edilen payların yok edilmesi olması da bu görüşümüzü desteklemektedir.

Şirketin kendi paylarının iktisabına ilişkin hükümler, ana şirketin paylarının yavru şirket tarafından iktisabı hâlinde de uygulanır (TTK m. 379/5). Ana şirket yavru şirket ilişkisi, TTK'de şirketler topluluğuna ilişkin hükümler altında düzenlenmektedir. Bu toplulukta hâkim şirketler ana, bağlı şirketler yavru şirket konumundadır (TTK m. 195/4). TTK m. 379/5 sadece TTK m. 195 vd anlamında hâkim şirket bağlı şirket ilişkisinin bulunduğu hâllerde uygulanır. Karşılıklı iştirak, hâkim şirket-bağlı şirket ilişkisi doğurmuyorsa, TTK m. 379/5 uygulanmaz ${ }^{25}$. Öğretide hüküm bağlamında, yavru şirket tarafından iktisap edilen paylar için yedek akçe ayrılması gerektiği ifade edilmektedir ${ }^{26}$.

20 Anonim şirket payının iktisabı "aslen ve devren" iktisap şeklinde gerçekleşmekle birlikte, şirketin kendi payını iktisap etmesi, ancak payın devren iktisabı ile gerçekleşir. Devren iktisap halinde, bir kişiye ait halen mevcut olan bir payın bir başkasının mülkiyetine geçmesi söz konusudur. Ayrıntılı bilgi için bkz. Türk (n 3) 27; Sevi, Pay (n 15 ) 40 vd.

21 Türk (n 3) 280; Turan (n 17) 41; Böckli (n 5) \$ 4 N 237 ve $\$ 8$ N 324; Handschin (n 2) Art. 659 N 24; Trüeb (n 4) Art. 659a N 14; Walter G Paefgen, iç Martin Henssler ve Lutz Strohn (edr), Gesellschaftsrechts (5. Bas1, C.H. Beck 2021$) \S 71$ N 40.

22 Böckli (n 5) \$ 4 N 263.

23 Poroy, Tekinalp ve Çamoğlu (n 2) 662; Türk (n 3) 280.

24 Böckli (n 5) \$ 8 N 275; Peter Böckli, OR-Rechnungslegung (2. Bası, Schulthess 2019) \$4 N 398; Paefgen (n 21) \$71 N 40.

25 Türk (n 3) 152. Ayrıntılı inceleme için bkz. Kadir Baş, 'Türk Ticaret Kanunu Uyarınca Anonim Şirketin Paylarının Yavru Şirketi Tarafından İktisap Edilmesi: Sorunlar, Saptamalar ve Öneriler’, iç Murat Alışkan, Bilge Utkan Mersin, Sinan Sarıkaya (edr), Sermaye Şirketleri Hukukunda Güncel Gelişmeler Sempozyumu (Tebliğler-Tartışmalar, 19 Haziran 2019) (On İki Levha 2020) $124 \mathrm{vd}$. 
Kanaatimizce de yavru şirketin ana şirketin paylarını iktisabı hâlinde de yedek akçe ayrılmalıdır. Zira TTK m. 520/1 de, anonim şirketin kendi paylarını iktisabına ilişkin hükümler arasındadır. Bunun yanı sıra, GAPT m. 20'de geri alınan payların geri alım bedeli kadar yedek akçe ayrılması gerektiği düzenlenmiştir. Geri alınan paylar, şirketin kendisi veya bağlı şirketleri tarafından satın alınan kendi paylarını ifade etmektedir (GAPT m. 4/1-f). Dolayısıyla GAPT'de yavru şirket tarafından ana şirketin paylarının iktisabı durumunda yedek akçe ayrılacağı açıkça düzenlenmiştir. Bununla birlikte, kanaatimizce bu durumun ve ayrıntılarının Tebliğ yerine TTK’de açıkça düzenlenmesi kanun yapıcılığı açısından daha yerinde olacaktır.

\section{Yedek Akçe Ayrılması}

\section{a. Genel Olarak}

TTK m. 520/1'de şirketin iktisap ettiği kendi payları için iktisap değerlerini karşılayan tutarda yedek akçe ayıracağı öngörülmüştür. Bununla birlikte öğretide bu yedek akçenin ayrılmasının pay iktisabının koşulu olup olmadığına ilişkin bir tartışma mevcuttur. Bir görüş TTK m. 520/1 bağlamında yedek akçe ayrılmamasının pay iktisabını geçersiz kılmayacağı yönündedir ${ }^{27}$. Zira yedek akçe ayrılması zorunluluğu, şirketin kendi paylarını edinmesinin bir koşulu olmayıp sonucudur ${ }^{28}$. Bu görüşte bulunan yazarlardan birine göre GAPT'de yer alan, geri alım için ayrılan fonun toplam tutarı ve kaynağının da geri alım programında belirtilmesini öngören düzenleme de varılan sonucu değiştirmeyecektir (Tebliğ, m. 8/1-f). Zira aksini kabul etmek, TTK m. 379'da getirilen koşullara ek bir koşul getirilmesi anlamına gelir. Oysa tebliğ hükmüyle bu yapılamaz. Bunun yanı sıra TTK m. 379/2-son uyarınca, yönetim kurulu her izin talebinde kanuni şartların gerçekleştiğini belirtecektir. Buna göre, yönetim kurulunca kanuni şartların her bir edinim öncesinde değerlendirilmesi gerekmektedir. Yoksa (yetki için izin istendiği/veya geri alım programı hazırlandığı) sırada koşulların tümü gerçekleştiği hâlde, payların edinildiği sırada, örneğin pay bedelini karşılayacak kadar özkaynak mevcut olmayabilir. Bunun tam tersine, şirketin elde etmesi kuvvetle muhtemel bir gelir beklentisi varsa, geri alım programında yeterli ölçüde fon ayrılması mümkün değilken, sonradan payların programa göre geri satın alınması mümkün olabilecektir. Bu nedenle söz konusu koşulu esnek değerlendirmek, mutlaka daha başlangıçta program için gerekli olan tutarda yedek akçe ayrılması gerektiği şeklinde anlamamak doğru olur ${ }^{29}$. Diğer bir görüşe göre anonim şirket bu yedek akçeyi ayırabilecek durumda değilse, - diğer şartları karşılayabilecek olsa bile - kendi paylarını satın alamaz ${ }^{30}$. Bu sebeple, söz konusu özel yedek akçe de bir anonim şirketin kendi paylarını satın alabilmesinin finansal koşullarındandır.

151; Oruç Hami Şener, Yargıtay Kararları Işığında Limited Ortaklklar Hukuku (Seçkin 2017) 163.

27 Sevi, Pay (n 15) 87; Türk (n 3) 280; Baş (n 25) 151; Lukas Glanzmann, 'Die Bilanzierung des Eigenkapitals im Einzelabschluss von Kapitalgesellschaften’ Schweizerische Zeitschrift für Wirtschafts - und Finanzmarktrecht (2017) $289<$ https://www.alexandria.unisg.ch/257247/1/SZW\%20Bilanzierung\%20des\%20EK.pdf> erişim tarihi 22.03.2021.

Türk (n 3) 280.

29 Türk (n 3) 438.

30 Poroy, Tekinalp ve Çamoğlu (n 2) 662. Yazarlar ayrıca bu akçeyi ayırmanın, iktisabın geçerlilik koşulu olmasa bile, işlemi yapabilmenin finansal koşulu olduğunu aksi hâlde yönetim kurulunun sorumlu olacağını ifade etmiştir [Bkz. 
Kanaatimizce iktisap edilen paylar için yedek akçe ayrılması, şirketin kendi paylarını iktisap edebilmesinin geçerlilik koşulu değil, bu iktisabın hukuki sonucudur. Zira TTK m. 520/1'de açıkça, yedek akçenin şirketin iktisap ettiği kendi payları için ayrılacağı düzenlenmiştir. Yoksa hükümde şirketin kendi paylarını iktisap edebilmesi için yedek akçe ayırması gerektiği düzenlenmemiştir. Keza GAPT m. 20'de de aynı düzenleme tarzı bulunmaktadır. Hüküm uyarınca geri alınan payların geri alım bedeli kadar yedek akçe ayrılarak özkaynaklar altında kısıtlanmış yedek olarak sınıflandırılır. Bunun yanı sıra, şirket payının ivazlı şekilde iktisabına ilişkin kural TTK m. 379/3’te yer almıştır. Burada sadece iktisap edilecek payların bedelleri düşüldükten sonra, kalan şirket net aktifinin, en az esas veya çıkarılmış sermaye ile kanun ve esas sözleşme uyarınca dağitılmasına izin verilmeyen yedek akçelerin toplamı kadar olması gerektiği düzenlenmiştir. Dolayısıyla şayet yedek akçe ayırmanın bir koşul olarak düzenlenmesi isteniyorsa bunun açıkça yapılması gerekir. Nitekim Alman Paylı Ortaklıklar Kanunu [Aktiengesetz (AktG)] \$ 71/2'de açıkça, şirketin payları iktisabına ancak iktisap değeri tutarında yedek akçe oluşturabiliyorsa izin verileceği ifade edilmiştir ${ }^{31}$. Ayrıca TTK m. 379'a aykırı bir şekilde iktisap edilen payların iktisap tarihinden itibaren en geç altı ay içinde elden çıkarılacağını düzenleyen TTK m. 384'te bu görüşümüzü desteklemektedir. Zira hüküm bağlamında, TTK m. 379’a aykırılık dahi iktisabı geçersiz kılmamakta sadece şirkete bunları elden çıkarma veya yok etme zorunluluğu getirmektedir. Dolayısıyla pay iktisabı için şirketin malvarlığının yeterli düzeyde olmaması dahi yapılan iktisabı geçersiz kılmıyorsa, yedek akçe ayırma yükümlülüğünün de geçersiz kılmaması gerekir. Son olarak, şirketin iktisap ettiği kendi payları için yedek akçe ayrılmasının sebebi, serbest özkaynaktan iktisap tutarı kadar bedeli çıkartarak bunu bağlı malvarlığı hâline getirmek ve genel kurulun bunlar üzerinde tasarrufunu engellemektir. Oysa şirketin yedek akçe ayıracak kadar bile serbest özkaynağı olmadığı için, şirketin özkaynağında genel kurulun kullanabileceği bir kalem de bulunmamaktadır. Dolayısıyla vardığımız bu sonuç, iktisap edilen paylar için yedek akçe ayrılması yükümlülüğünün amacıyla da çelişmemektedir. Bununla birlikte, yedek akçe ayırmak şirketin kendi paylarını iktisabının sonucu olduğu için, şayet yedek akçe ayıracak kadar malvarlığı bulunmuyorsa bu yönetim kurulunun sorumluluğunu gündeme getirecektir. Zira yönetim kurulu şirketin kendi paylarını iktisabı ile görevlendirilmiştir (TTK m. 379/2).

\section{b. Yedek Akçe Ayırmakla Yükümlü Şirketin Belirlenmesi}

Kendi paylarını iktisap eden anonim şirketin, bu iktisabın sonucu olarak yedek akçe ayırması gerekir. Bununla birlikte, ana şirket yavru şirket ilişkisi olduğunda kimin yedek akçe ayırması gerektiğine ilişkin TTK'de bir düzenleme bulunmamaktadır. Öğretide bir görüş yedek akçeyi yavru şirketin

Poroy, Tekinalp ve Çamoğlu (n 2) 660]. Turan, eserinde öncelikle iktisap tutarı değerinde yedek akçe ayırmasını şirketin kendi paylarını iktisap edebilmesinin diğer bir koşulu olarak göstermiştir. Bununla birlikte, yazar daha sonra TTK m. 520/1 uyarınca yedek akçe ayrılmasının, şirketin kendi paylarını edinmesinin bir şartı olmayıp, sonucu olduğunu ve bu sebeple, yedek akçe ayrılmamasının iktisabın geçerliliğine etki etmeyeceğini belirtmiştir. Bkz. Turan (n 17) 41-42.

31 Bununla birlikte, AktG $₫ 71 / 4$ c.l'de ikinci fikranın ihlalinin iktisabın geçerliliğini etkilemeyeceği düzenlenmiştir. Buna karşılık, $\$ 71 / 4$ c. 2 uyarınca bu ihlal, pay alımına ilişkin borçlandırıcı işlemi geçersiz kılacaktır. Bu sebeple, yedek akçe ayıracak kadar serbest malvarlığı olmamasına rağmen şirket kendi paylarını iktisap etmişse, pay iktisabı geçerli olmakla birlikte buna ilişkin borçlandırıcı işlem geçersiz olacaktır. Bkz. Grigoleit ve Rachlitz (n 5) $₫ 71$ N 150; Uwe Hüffer ve Jens Koch, iç Uwe Hüffer ve Jens Koch (edr), Aktiengesetz (15. Bası, C.H. Beck 2021) §71 N 21a; Paefgen (n 21) §71 N 45. 
ayırması gerektiği yönündedir ${ }^{32}$. Zira payları edinen yavru şirket olduğundan, ana şirketin yedek akçe ayırması muhasebe tekniği açısından mümkün değildir. Alman Hukuku'nda da uygulama bu yöndedir ${ }^{33}$. Buna göre, iktisap edilen paylar bağlı şirketin varlık kısmında raporlanacak ve buna karşılık özkaynakta yedek akçe yaratılacaktır³ ${ }^{34}$ Buna karşılık öğretide başka bir görüş, ana şirketin yedek akçe ayırmakla yükümlü olduğu yönündedir ${ }^{35}$. Zira payları iktisap edilen yavru şirket değil, ana şirkettir. Keza yavru şirketin bir anonim şirket olmak zorunda olmaması da bu sonu haklı kılar. Bunun yanı sıra öğretide, bağlı şirket tarafından ana şirketin paylarının devralınmasına, yalnızca, ana şirketin AktG $\$ 71 / 2$ uyarınca bu paylar için yedek akçe yaratabilecek kadar serbest özkaynağ1 bulunması durumunda izin verileceği ifade edilmektedir ${ }^{36}$. Bununla birlikte, İsviçre Hukuku'nda İsviçre Borçlar Kanunu (Obligatioenenrecht - OR-) Art. 659b/3’te açıkça çoğunluğa ${ }^{37}$ sahip olan ana şirketin yedek akçe ayırması gerektiği düzenlenmiştir. Bu sebeple öğretide, ana şirketin yedek akçe ayırması gerektiği; çünkü kanunen payı kendi almış gibi görüldüğü ifade edilmektedir. Buna karşılık, yavru şirketin yapmış olduğu bu alım sebebiyle yedek akçe ayırması gerekmez ${ }^{38}$. Bu sayede, yedek akçe ana şirketin kârından karşılanacak ve ana şirketin bu tutarı kâr olarak dağıtması engellenecektir ${ }^{39}$. Bunun yanı sıra, öğretide bağlı şirketin ana şirketin paylarını, amaçlanan elde tutma süresine bağlı olarak dönen varlıklar veya sabit varlıklar olarak raporlayacağı ifade edilmektedir ${ }^{40}$.

TTK açısından değerlendirildiğinde, TTK ve KGK düzenlemelerinde kimin yedek akçe ayıracağına ilişkin açık bir düzenleme yoktur. Bununla birlikte, Büyük ve Orta Boy İşletmeler İçin Finansal Raporlama Standardı ${ }^{41}$ (BOBİ FRS) m. 9.69'da bağlı şirketin elinde bulundurduğu işletmenin payları

32 Türk (n 3) 283; Poroy, Tekinalp ve Çamoğlu (n 2) 663; Karacan ve Erişir Karacan (n 17) 160; Ayan (n 13 ) 216.

33 Bir işletmenin, kendisine hâkim veya kendisinde çoğunluk paya sahip işletmenin paylarını edinmesi durumunda, yedek akçe ayırmaya ilişkin AktG $\$ 71 / 2$ ye uyulacaktır (AktG $\$ 71 \mathrm{~d}$ ). Bunun yanı sıra, bilançonun yapısını düzenleyen Alman Ticaret Kanunu [Handelsgesetzbuch (HGB)] \$266'da bilançonun pasifinde özkaynak grubunun altında hâkim veya çoğunluk paya sahip işletme için yedek akçe kalemi bulunmaktadır [HGB \$266/3A(3-2)]. Ayrıca özkaynağa ilişkin HGB $\$ 272$ 'de ise, hâkim veya çoğunluk paya sahip bir işletmedeki paylar için yedek akçe ayrılacağı açıkça düzenlenmiştir (HGB \$272/4).

34 Bruno Kropff, iç Joachim Hennrichs, Detlef Kleindiek ve Christoph Watrin (edr), Münchener Kommentar zum Bilanzrecht, Band 2, S\$ 238-342e Handelsgesetzbuch (C.H. Beck 2013) \$ 272 N 207; Moritz Pöschke, iç Martin Henssler, Carsten Herresthal, Marian Paschke (edr), beck-online.Grosskommentar zum Bilanzrecht, $\$ \$ 238$ - 342e Handelsgesetzbuch (C.H. Beck 2020) § 272 N 218; Robert Winnefeld, Bilanz-Handbuch (5. Bas1, C.H. Beck 2015) Kapitel D, N 1850.

35 Baş (n 25) 152. Limited şirketler açısından aynı yönde bkz. Şener, Limited (n 25) 163.

36 Pöschke (n 34) \$272 N 219; Kropff (n 34) \$272 N 208.

37 OR Art. 659b/3’te sadece çoğunluk kavramı geçmektedir. Bu sebeple İsviçre öğretisinde, bunun sermayenin mi yoksa oyların çoğunluğu mu olduğu tartışmalıdır. İnceleme için bkz. Lenz ve von Planta (n 1) Art. 659b N 3; Handschin (n 2) Art. $659 \mathrm{~N} 153 \mathrm{vd}$.

38 Forstmoser, Meier Hayoz ve Nobel (n 4) $\$ 50$ N 182; Neuhaus ve Balkanyi (n 10) Art. 671a N 5d, 10a; Lukas Glanzmann, 'Das neue Rechnungslegungsrecht' iç Peter V Kunz, Oliver Arter ve Florian Jörg (edr), Entwicklungen im Gesellschaftsrecht VIII (Stämpfli 2013) 289; Lenz ve von Planta (n 1) Art. 659b N 9; Christian Haas, 'Eigene Aktien und Kapitalverlust' (2013) (12) Der Schweizer Treuhänder 921, 926; Böckli, Rechnungslegung (n 24) $\$ 4$ N 486; Handschin, 'Aktien' (n 17) 488; Imark ve Lipp (n 6) Art. 671a N 8.

39 Handschin (n 2) Art. 659 N 166.

40 Neuhaus ve Balkanyi (n 10) Art. 671a N 5d; Lenz ve von Planta (n 1) Art. 659b N 9; Imark ve Lipp (n 6 ) Art. 671 a N 8. Diğer görüşe göre bağlı ortaklık, iktisap edilen payları özkaynağı azaltıcı şekilde raporlamalıdır. Bkz. Handschin, 'Aktien' (n 17) 487-488; Glanzmann, 'Bilanzierung' (n 27) 288.

41 “Büyük ve Orta Boy İşletmeler İçin Finansal Raporlama Standardı Hakkında Tebliğ”in ekinde yayınlanmıştır. Bkz. RG 29.07.2017/30138 mük. 
konsolidasyon sırasında, varsa kontrol gücü olmayan paylara isabet eden tutarlar da dahil olmak üzere, tamamıyla elimine edileceği ve karşıllğıında da özkaynak tutarının azaltılacağı yer almıştır. Buna göre, ana şirket konsolide finansal tablosunu hazırlarken, bağlı şirketin edinmiş olduğu payları bilançonun özkaynak grubunda, özkaynak tutarını azaltacak şekilde raporlayacaktır. Bunun için de, finansal tablolarda özel bir raporlama şekli oluşturulmuştur. Şirketin kendi edindiği paylar, "Geri Alınmış Paylar" hesabında raporlanırken, bağlı şirket tarafından edinilen paylar "Karşılıklı İştirak Sermaye Düzeltmesi” hesabında raporlanır ${ }^{42}$. Dolayısıyla BOBİ FRS bağlamında, bağlı şirket tarafından iktisap edilen hakim şirket payları, hakim şirketin hazırlamış olduğu konsolide finansal tablolarda raporlanacaktır. Buna karşıllık yedek akçeyi kimin ayırması gerektiğine yönelik herhangi bir açıklama yapılmamıştır. Kanaatimizce bu sorun yavru şirket tarafından ana şirketin paylarını iktisabının ana şirketin kendi paylarını iktisabına eşdeğer görmemizin nedeni ekseninde çözülmelidir ${ }^{43}$. Buna göre, TTK m. 379/5 ile ana şirketin sermayesi ile oy dengelerini korumak ve yavru şirketler aracılığıyla payların yasağa aykırı iktisabını engellemek amaçlanmaktadır ${ }^{44}$. Dolayısıyla ana şirket, kendi paylarını iktisabına rağmen kâr payı dağıtımına devam etmek için yavru şirket aracılığıyla kendi payını iktisap edebilir. Buna karşlık, yavru şirkette ana şirketteki payların bulunması, bir şirketin kendi paylarını doğrudan iktisabında olduğu gibi, kâr payı ödemesinde sermayenin geri ödemesi riskini içermez ${ }^{45}$. Bu sebeple, kanaatimizce ana şirket yedek akçe ayırmakla yükümlü olmalıdır. Nitekim BOBİ FRS'de yavru şirket tarafından edinilen payların konsolide finansal tabloda gösteriliş biçimi de bu görüşümüzü desteklemektedir. Zira bu paylar ana şirket tarafından hazırlanan konsolide bilançoda raporlanarak, ana şirketin serbest özkaynak tutarı azaltılmıştır. Ayrıca uygulamada da bağlı şirket tarafından yapılan alımlar, ana şirketin hazırladığ 1 konsolide bilançoda geri alınmış paylara ilişkin yedek hesabında gösterilmektedir ${ }^{46}$. Yavru şirket ise, edindiği payları varlık olarak raporlayacaktır ${ }^{47}$. Son olarak kanaatimizce muhasebeleștirilmeye ilişkin kuralları da etkileyecek bu durumun TTK'de açıkça düzenlenmesi gerekir.

\section{c. Yedek Akçe Olarak Ayrılacak Tutar}

Şrketin kendi paylarını iktisap etmesi durumunda, şirketin ayıracağ yedek akçe tutarı iktsap değerindedir (TTK m. 520). Bu tutar, satın alma fiyatına karşılık gelir ${ }^{48}$. Bunun yanı sıra, payın

42 Finansal Tablo Örnekleri ve Kullanım Rehberi (FTÖKR) 62. Rehber için bkz. RG 07.06.2019/30794.

43 Kendi hisselerinin satın alınması ile ilgili olarak, grup tarafından tek bir işlem vardır. Kuralın amacı, grup şirketlerinin aracıları tarafından kendi hisselerinin satın alınmasına ilişkin kuralların atlanmasını önlemektir. Handschin (n 2) Art. 659 N 152.

44 Tekinalp, Sermaye (n 7) 123; Kropff (n 34) § 272 N 206; Pöschke (n 34) § 272 N 217; Böckli (n 5) § 4 N 327-332; Baş (n 25$) 123$.

45 Lenz ve von Planta (n 1) Art. 659b N 9.

46 Lokman Hekim Engürü Sağlık, Turizm, Eğitim Hizmetleri ve İnşaat Taahhüt A.Ş. genel kurulu yapmış olduğu geri alım programında, 01.04.2018 tarihinden sonra paylarının bağlı şirketi tarafından satın alacağını belirlemiştir. Program kapsamında Lokman Hekim Van Sağlık Hizmetleri İnşaat Taahhüt ve Ticaret A.Ş. geri alımda bulunabilecek bağlı şirketlerindendir. Şirketin yapmış olduğu alım için ana şirketin konsolide finansal tablosunda yedek akçe ayrılmıştır. Bkz. <file:///C:/Users/Bahattin\%20Çamcı/Downloads/Lokman\%20Hekim\%20122020\%20BDR.pdf>; 2018 yllında yapılan alımlar için bkz. <https://lokmanhekim.com.tr/finansal-tablo-ve-dip-notlar/> erişim tarihi 22.03.2021.

47 Yavru şirketin iktisap ettiği ana şirketin paylarını ne şekilde raporlayacağının incelenmesi için bkz. II. B. Şirketin İktisap Ettiği Kendi Payları Açısından.

48 Neuhaus ve Balkanyi (n 10) Art. 671a N 11; Böckli (n 5) § 8 N 324. 
nominal/itibari değerinin iktisap tutarından farklı olması, ayrılacak yedek akçe tutarını etkilemez ${ }^{49}$. Örneğin Aksu Gıda anonim şirketi 5.000 TL nominal değerli kendi payını, pay sahibi A’dan 10.000 TL karşılığında satın almıştır. Bu durumda şirketin kendi payları için oluşturacağı yedek akçe tutarı 10.000 TL olacaktır.

Yedek akçe olarak ayrılacak tutar, şirketin serbestçe kullanılabilen özkaynağından karşılanır ${ }^{50}$. Sebestçe kullanılabilen özkaynaktan kasıt, TTK, esas sözleşme veya genel kurul kararıyla kullanımı herhangi bir şekilde kısıtlanmamış şirket kaynağıdır. Buna ilk olarak serbest yedek akçeler dâhildir ${ }^{51}$. Serbest yedek akçeler, genel kanuni yedek akçelerin sermayenin veya çıkarılmış sermayenin yarısını aşan kısmı (TTK m. 519/3), belirli bir amaca tahsis edilmeden, esas sözleşme gereği ayrılan yedek akçeler (TTK m. 521) ve genel kurulca ayrılmasına karar verilen (TTK m. 523/2) yedek akçelerdir ${ }^{52}$. TTK m. 519'da genel kanuni yedek akçenin, dört farklı kaynaktan oluştuğu düzenlenmiştir. Buna göre, yıllık kârın yüzde beşi, ödenmiş sermayenin yüzde yirmisine ulaşıncaya kadar genel kanuni yedek akçeye ayrılır (TTK m. 519/1). Bu ayrım yapıldıktan sonra pay senedi ihraç primleri, pay senedi iptal kârları ve kârdan pay alacak kişilere dağıtılacak tutarın yüzde onu genel kanuni yedek akçeye eklenir [TTK m. 519/2(a-c)]. Bu dört kaynağın sermayenin yarısını aşması durumunda, aşan kısım serbest yedek akçe olarak nitelendirilir. Bunun yanı sıra, bilançoda bulunan geçmiş yıllar kârı hesabında ${ }^{53}$ bulunan tutar da, şirketin serbest kaynakları arasındadır. Ayrıca şirketin ilgili faaliyet yılında elde edilmiş ve gerekli ayrımlar yapılmış dönem net kârı hesabı da yedek akçe ayırmak için kullanılabilecektir ${ }^{54}$. Bu yedek akçenin payların anonim şirket tarafından iktisabı tarihinde ayrılması gerekir ${ }^{55}$. Aksi hâlde yönetim kurulu sorumlu olur.

\section{Ayrılan Yedek Akçenin Çözülmesi}

\section{a. Genel Olarak}

TTK m. 520/1 uyarınca şirketin kendi payları için ayırdı ̆̆ 1 yedek akçeler, anılan paylar devredildikleri veya yok edildikleri takdirde iktisap değerlerini karşılayan tutarda çözülebilirler. Hükümde öngörülen durumlar oluşmadıkça, şirket kendi paylarına ilişkin yedek akçeleri üzerinde tasarrufedemez. Örneğin

49 Tekinalp, Sermaye (n 7) 110; Turan (n 17) 41.

50 Neuhaus ve Balkanyi (n 10) Art. 671a N 5c; Böckli (n 5) \$ 8 N 326; Handschin (n 2) Art. 659 N 71; Imark ve Lipp (n 6) Art. 671a N 2; Türk (n 3) 281; Can Sözer, Anonim Şirketlerin Kendi Paylarını İtisabının Vergisel Sonuçları (2. Bası, İstanbul 2014) 137; Ayan (n 13) 213.

51 Neuhaus ve Balkanyi (n 10) Art. 671a N 5c; Böckli (n 5) \$ 8 N 326; Handschin (n 2) Art. 659 N 71; Türk (n 3) 281; Ayan (n 13) 213.

52 Veliye Yanlı, 'Anonim Şirketlerde Kâr Dağıtımı' (2014) XXX(1) Banka ve Ticaret Hukuku Dergisi 5, 8.

53 Bu hesap, geçmiş faaliyet dönemlerinde ortaya çıkan ve pay sahiplerine dağıtılmamış kârlardan ilgili yedek hesaplarına alınmayan karların izlenmesinde kullanılır. İnceleme için bkz. Raziye Aksu Özkan, Finansal Tabloların Tutulması ve Hukuksal Sonuçları (On İki Levha 2019) 284; Erhan Bayazıtlı, Orhan Çelik ve Kadir Gürdal, Genel Muhasebe (Siyasal 2016) 502.

54 Böckli (n 5) \$ 8 N 326; Handschin (n 2) Art. 659 N 71; Türk (n 3) 281.

55 Neuhaus ve Balkanyi (n 10) Art. 671a N 10; Poroy, Tekinalp ve Çamoğlu (n 2) 662; Türk (n 3) 281; Sözer (n 50 ) 137. 
bilanço zararının ilgili yedek akçe ile kapatılmasına izin verilmez ${ }^{56}$. Keza bu yedek akçeler sermaye artırımında kullanılamayacağı gibi kâr payı olarak pay sahiplerine de dağıtılamaz ${ }^{57}$. Bununla birlikte, kanaatimizce hükümdeki "çözülebilirler" ifadesi, söz konusu durumlar gerçekleştiğinde genel kurula takdir hakkı verildiği şeklinde yorumlanmamalıdır. Kanunda sayılan hâller gerçekleştiğinde, iktisap için ayrilan yedek akçe de çözülmelidir ${ }^{58}$. Zira yedek akçe ayırmanın sebebi ortadan kalkmıştır. Söz konusu durumlar gerçekleşmişse, kendi payları için ayrılan yedek akçeden serbest bırakılan tutar serbest yedeklere aktarılmalıdır ${ }^{59}$. Buna göre, çözülen tutar serbestçe kullanılabilir. Örneğin kâr olarak dağıtılabilir veya sermayeye eklenebilir ${ }^{60}$.

\section{b. Çözülebileceği Hâller}

Şrketin kendi payları için ayırdığı yedek akçelerin çözülebileceği ilk hâl, anılan payların devredilmesidir (TTK m. 520). Devredilme, üçüncü kişilere kendi paylarının satışını veya satışla aynı ekonomik etkiye sahip hukuki bir işlemi içerir. Örneğin bağış, alacaklının iddiasına karşı mahsup etme gibi ${ }^{61}$. Bununla birlikte, TTK'de ana şirketin iktisap ettiği kendi payını, bağlı şrkete devretmesi hâlinde ne yapılacağı düzenlenmemiştir. İsviçre öğretisinde bir görüş ana şirketin sahip olduğu kendi paylarının bir bağlı şirkete satışını, yedek akçenin çözülmesini gerektirecek bir satış olarak nitelendirmemektedir. Bu durumda da, ana şirketin kendi payları için yedek akçe ayırması gerekir ${ }^{62}$. Bununla birlikte, bağlı şirketin ana şirketteki payları üçüncü kişilere satması farklıdır. $\mathrm{Bu}$, ana şirketteki kendi payları için ayrılan yedek akçenin serbest bırakılmasına yol açar ${ }^{63}$. Bunun yanı sıra, şirketin kendi payları için ayırdığı yedek akçeler, anılan paylar yok edildikleri takdirde de çözülebilir (TTK m. 520). Payların yok edilmesi sermayenin azaltılması yoluyla TTK m. 473 ve 475 çerçevesinde gerçekleştirilecektir.

\section{c. Çözülecek Tutar}

TTK m. 520/1 uyarınca, çözülecek yedek akçe tutarı, devredilen veya yok edilen payların iktisap değerlerini karşılayan tutardır. Dolayısıyla şirketin iktisap ettiği payları iktisap değerinden daha fazla veya azı tutarında elden çıkarmış olması, çözülecek yedek akçe tutarını etkilemeyecektir. Böylece paylar daha yüksek bir bedelle elden çıkarılırlarsa hem yedek akçelerin daha hızlı çözülmesi önlenmek hem de bunun şirket hesaplarını manipüle etmek amacı ile kullanılması engellenmek

56 Böckli (n 5) \$ 8 N 333; Kropff (n 37) \$272 N 220; Pöschke (n 34) \$272 N 230.

57 Böckli (n 5) \$8 N 333.

58 Kropff (n 34) § 272 N 220; Pöschke (n 34) § 272 N 230.

59 Stephan Dekker, iç Jeannette K. Wibmer (ed), Aktienrecht Kommentar Aktiengesellschaft, Rechnungslegungsrecht, VegüV, GeBüV, VASR (Orell Füssli 2016) Art. 671a N 9; Imark ve Lipp (n 6) Art. 671a N 9; Turan (n 17) 42; Karacan ve Erişir Karacan (n 17) 160.

60 Karacan ve Erişir Karacan (n 17) 160; Otlu, Bekçi ve Karataş (n 4) 289.

61 Dekker (n 59) Art. 671a N 3.

62 ibid Art. 671a N 3.

63 Dekker (n 59) Art. 671a N 3; Imark ve Lipp (n 6) Art. 671a N 9. 
istenilmiştir ${ }^{64}$. Satış için zaman açısından belirleyici nokta, elden çıkarma işlemidir; yok etme için ticari siciline kayıttır ${ }^{65}$.

Çözülecek tutarın tespiti, şirketin kendi paylarını farklı fiyatlardan iktisap etmesi durumunda önem arz etmektedir. Buna göre, iktisap edilen kendi payların sadece bir kısmı satılır veya yok edilirse, bu durumda, kendi payları için serbest bırakılacak ilgili yedek akçe tutarını belirlemek için sistematik bir prosedür seçilmelidir ${ }^{66}$. Şirket, düşülecek tutarı belirlemek için LIFO (Last-In First-Out/Son giren ilk çıkar), FIFO (First-In First-Out/İlk giren ilk çıkar) veya ortalama değer yöntemini kullanabilir ${ }^{67}$. Seçilen prosedür, yıllık finansal tablo dipnotlarında açıklanmalı ve tutarlı bir şekilde uygulanmalıdır.

\section{Hükme Aykırılığın Sonuçları}

TTK m. 520'de şirketin edindiği paylar için yedek akçe ayırma yükümlülügü düzenlenmekle birlikte, hükme aykırılığın yaptırımı özel olarak düzenlenmemiştir. Bu sebeple, her durum ayrıca değerlendirilmelidir. İlk olarak bu yükümlülüğe aykırı davranış, şirketin kendi paylarını iktisabını geçersiz kılmaz. Zira iktisap edilen paylar için yedek akçe ayrılması, şirketin kendi paylarını edinmesinin koşulu değil sonucudur. İkinci olarak iktisap edilen paylar için yedek akçe ayrılmaksızın hazırlanan yıllık bilançonun geçerliliği farklı ihtimallere göre değerlendirilmelidir. Buna göre şirketin yedek akçe ayıracak kadar serbest özkaynağı bulunmasına rağmen, bu yedek akçe ayrılmaksızın bilanço hazırlanmışsa, bu bilanço denetimden geçemeyecektir ${ }^{68}$. Zira finansal tabloların TTK ve KGK yayınlarına uygun şekilde hazırlanması gerekir (TTK m. 398). Bunun yanı sıra, şirketin yedek akçe ayıracak serbest özkaynağı olmaması durumunda da kural olarak aynı sonuca varılmalıdır. Bununla birlikte, kanaatimizce bu durumda yönetim kurulunun bilançoda ayrılması gereken yedek akçe tutarı kadar zarar göstermesi ve bilanço dipnotlarında bunun açıklamasını yapması durumunda farklı bir sonuca varılabilir. Böylece şirket yeniden serbest özkaynak elde edene kadar raporlanan zarar, ileride elde edilecek kârın dağıtımını engelleyecektir ${ }^{69}$. Bu durumda, bilançonun sınırlı olumlu görüş yazısı verilerek denetimden geçirilmesi mümkündür (TTK m. 403/3). Bu görüş yazısında denetçi, olumlu görüşünü sınırlandırmasının sebebi olarak yedek akçe ayrılmamasını açıkça belirtebilir. Üçüncü olarak yedek akçe ayrılmaksızın ve gerekli açıklamalar yapılmaksızın hazırlanan bilanço bir şekilde denetimden geçmiş ve genel kurul bunu onaylamışsa, genel kurulun bilançonun onaylanmasına ilişkin kararı butlanla batıl olacaktır ${ }^{70}$. Keza bu bilançoya dayanılarak alınan kâr dağıtımı kararı da butlanla batıldır ve dağıtılan kâr da haksız kâr oluşturur. Son olarak bu yükümlülüğe aykırı davranış TTK m. 553 uyarınca kanuna aykırılık sebebiyle yönetim kurulunun sorumluluğuna sebep

64 Karacan ve Erişir Karacan (n 17) 160.

65 Dekker (n 59) Art. 671a N 8.

66 Dekker (n 59) Art. 671a N 7; Neuhaus ve Balkanyi (n 10) Art. 671a N 17.

67 Dekker (n 59) Art. 671a N 7; Neuhaus ve Balkanyi (n 10) Art. 671a N 17; Glanzmann, 'Bilanzierung' (n 27) 286; Imark ve Lipp (n 6) Art. 671a N 9.

68 Kropff (n 34) § 272 N 220.

69 Winnefeld (n 34) Kapitel D N 1853.

70 Sevi, Pay (n 15) 87. 
olabilir $^{71}$ (TTK m. 553). Bunun için şirketin zarara da uğraması gerekir. Bununla birlikte, TTK m. 520/1 uyarınca yedek akçe ayrılması, sadece özkaynaklarda vasıf değişikliğine yol açtığı için, bu yükümlülüğe uyulmaması tek başına bilanço zararına yol açmaz. Buna karşılık, şirket bağlı yedek akçe ayırmadığı için bu tutar pay sahiplerine kâr olarak dağıtılırken, edinilen paylar da satılamadığı için sermaye azaltımı suretiyle itfa edilirse veya şirket kendi payları satılmadan tasfiyeye girerse bilanço zararı ortaya çıkar 72 .

\section{II. Şirketin İktisap Ettiği Kendi Paylarının ve Bunun İçin Ayrılan Yedek Akçenin Muhasebeleştirilmesi}

\section{A. Genel Olarak}

TTK'de finansal tablolara ilişkin uygulanacak esas kurallar açısından KGK’nin düzenlemelerine gönderme yapılmıştır (TTK m. 88). KGK, bu hususta Türkiye Muhasebe Standartları/Türkiye Finansal Raporlama Standartları (TMS/TFRS), BOBİ FRS ve Muhasebe Sistemi Uygulama Genel Tebliği (MSUGT) şeklinde üç tür mevzuat belirlemiştir ${ }^{73}$. Bu üç mevzuat açısından da şirketin iktisap ettiği paylar ve bunlara ilişkin ayrılan yedek akçe, anonim şirketin bilançosunda muhasebeleştirilir. TTK'de açıkça bilançonun tanımına yer verilmemiştir; ancak TTK m. 68/1'de bilançonun işletmenin varlık ve borçlarının tutarlarının ilişkisini gösteren finansal tablo olduğu yer almıştır. KGK’nin düzenlemelerinde ${ }^{74}$ ve öğretide bilanço, "hazırlandığı tarih itibariyle işletmenin varlık, yükümlülük ve özkaynaklarını gösteren tablo” şeklinde tanımlanmaktadır ${ }^{75}$. Finansal raporlamada, şirketin gerçekleştirdiği iktisadi işlemler, niteliklerine göre varlık, yükümlülük veya özkaynak gruplarına aktarılır. Anonim şirketin sahip olduğu varlıklar, ya şirket kurucuları tarafından sağlanmıştır ya da üçüncü kişilere borçlanılarak elde edilmiştir. Bunlardan birinci bölümün kaynağına "Özkaynak", ikinci bölümün kaynağına "Yükümlülükler” denilir (FRKÇ m. 4.1/a). Şirketin kuruluşunda sadece sermayeden oluşan özkaynak grubuna, şirketin faaliyetleri arttıkça farklı hesaplar eklenir ${ }^{76}$.

71 Sevi, Pay (n 15) 87; Poroy, Tekinalp ve Çamoğlu (n 2) 662.

72 Türk (n 3) 283.

73 Kurul kararı için bkz. <http://kgk.gov.tr/Portalv2Uploads/files/PDF\%20linkleri/RGTMS\%20Uygulama\%20 Kapsam\%C4\%B1na\%20\%C4\%B0li\%C5\%9Fkin\%20Kurul \%20Karar\%C4\%B1_y.pdf> erişim tarihi 20.02.2021.

74 TMS/TFRS'de de bilançonun tanımı açıkça düzenlenmemiş; ancak KGK tarafından yayınlanan Finansal Raporlamaya İlişkin Kavramsal Çerçeve (FRKÇ) m. 3.3/ảda bilançoda varlık, yükümlülük ve özkaynak unsurlarının bulunacağına yer verilmiştir (FRKÇ için bkz. RG 27.10.2018/30578). BOBİ FRS m. 1.29 uyarınca bilanço, işletmenin finansal durumu hakkında bilgi vermek üzere hazırlanan ve işletmenin belirli bir tarihteki varlık, yükümlülük ve özkaynaklarını gösteren tablodur.

75 Orhan Sevilengül, Genel Muhasebe (18. Bası, Gazi 2016) 33; Gürbüz Gökçen, Genel Muhasebe (Beta 2015) 9; Ahmet Gökgöz, Genel Muhasebe (Ekin 2015) 5; Tolga Uysal ve Mehmet Şenlik, Genel Muhasebe (Seçkin 2016) 31; Bayazıtlı, Çelik ve Gürdal (n 53) 26; Erhan Yalçın, Uluslararası Finansal Raporlama (Seçkin 2015) 214; Aksu Özkan (n 53) 166; Karayalçın, bilançonun içeriğinden bahsetmeksizin, bilançoyu işletmenin dönem sonu mali "muvazene=denge"sini gösteren belge olarak tanımlamıştır. Bkz. Karayalçın (n 10) 40; Tekinalp, bilanço için bir tanım vermekten kaçınmaktadır. Yazara göre bunu yapmaya çalışmak, bilanço gibi zengin içeriğe sahip kavramlar açısından tanıtıcı olmamaktadır. Bu sebeple, bilançonun sonuç açıklama işlevine değinmektedir. Bkz. Ünal Tekinalp, Anonim Ortaklı̆̆ın Bilançosu ve Yedek Akçeleri (2. Bası, Fakülteler 1979) 59-60.

76 Özkaynaklar grubunda, ödenmiş sermaye, sermaye düzeltme farkları, sermaye katkıları, paylara ilişkin primler/ iskontolar, kârdan ayrılan kısıtlanmış yedekler ve fonlar, kâr veya zararda yeniden sınıflandırılmayacak özkaynaklarda kaydedilen birikmiş gelirler (giderler), kâr veya zararda yeniden sınıflandırılacak özkaynaklarda kaydedilen birikmiş 
Bunlardan biri de şirketin iktisap ettiği kendi payları için ayrılan kanuni yedek akçeye ilişkin hesaptır. Bunun yanı sıra, bilanço aktif ve pasif taraf ayrımına da tâbi tutulmaktadır. Tablonun sol yanına aktif taraf, sağ yanına da pasif taraf denir ${ }^{77}$. Aktif taraf, o şirketin varlıklarını; pasif tarafsa bu varlıkların nasıl finanse edildiğine dair bilgileri içeren yükümlülükleri ve özkaynaklarını gösterir ${ }^{78}$. $\mathrm{Bu}$ ayrım kapsamında yedek akçeler, bilançonun pasifinde raporlanır ve bilançonun aktifinde yer alan bir kısım varlığın kaynağını oluşturur. Şirketin iktisap ettiği kendi payları için ayrılan yedek akçe ise, şirketin iktisap ettiği kendi paylarının kaynağı olarak raporlanır. Bu sebeple, şirketin iktisap ettiği kendi payları ve bunun için ayrılan yedek akçenin muhasebeleştirilmesi bu düzenlemeler bağlamında ayrı ayrı ele alınacaktır.

\section{B. Şirketin Ikisap Ettiği Kendi Payları Açısından Muhasebeleştirme}

KGK tarafından yayınlanan “TMS 32 Finansal Araçlar: Sunum ${ }^{79 ”}$ standardından önce, şirketin iktisap ettiği kendi payları şirketin varlığ olarak bilançonun aktifinde muhasebeleştiriliyordu ${ }^{80}$. Eski sistemde şirketin iktisap ettiği kendi payları, şirket açısından varlık kalemleri arasındaki bir değişimden ibaret olup, şirketin varlık tutarında bir değişikliğe sebep olmuyordu. Örneğin Aksu Gıda A.Ş.nin esas sermayesi 100.000 TL olup tamamı nakit ödenmiştir. Her bir payın değeri 10.000 TL olup, 10 tane payı vardır. Şirketin 10.000 TL kanuni yedek akçesi ve 40.000 TL'de geçmiş yıllardan aktarılan kârı vardır. Bunların karşılığında, şirketin 150.000 TL nakit parası bulunmaktadır. Bu tutar, bilançonun dönen varlık kısmında nakit hesabında gösterilecektir. Buna ilişkin bilanço, Tablo l'deki şekilde gösterilecektir:

Tablo I:

\begin{tabular}{|c|c|}
\hline \multicolumn{2}{|c|}{ AKSU GIDA ANONIM ŞIRKETI’NIN 31 ARALIK 2020 TARIHLİ BİLANÇOSU } \\
\hline VARLIK/AKTIF & KAYNAK/PASIF \\
\hline $\begin{array}{l}\text { Dönen Varlık } 150.000 \text { TL } \\
\text { Nakit hesabı } 150.000 \text { TL }\end{array}$ & $\begin{array}{l}\text { Yükümlülükler } 0 \\
\text { Özkaynak } 150.000 \mathrm{TL} \\
\text { Ödenmiş sermaye } 100.000 \mathrm{TL} \\
\text { Kârdan ayrılan kısıtlanmı̧ yedek } 10.000 \mathrm{TL} \\
\text { Geçmiş yllardan aktarılan kâr } 40.000 \mathrm{TL}\end{array}$ \\
\hline
\end{tabular}

Aksu Gıda şirketi, 10.000 TL’lik bir payını, pay sahibi P’ye 10.000 TL ödeyerek iktisap etmiştir. Bu durumda, şirketin nakit hesabı 10.000 TL azaltılacak; ancak bunun yerine varlık kısmında iktisap

gelirler (giderler), geçmiş yıllar kârları, geçmiş yıllar zararları ve dönem net kârı (zararı) hesapları bulunur. İnceleme için bkz. Aksu Özkan (n 53) 241-287.

77 Böckli, Rechnungslegung (n 24) § 4 N 306; Gökgöz, Genel (n 75) 5; Uysal ve Șenlik (n 75) 31; Nihat Küçüksavaş, Finansal Muhasebe (14. Bası, Beta 2016) 57; Tanıs (n 11) 19; Yalçın (n 75) 214; Bayazıtlı, Çelik ve Gürdal (n 53) 26; Tekinalp (n 75) 162.

78 Gökgöz, Genel (n 75) 5; Tanış (n 11) 19.

79 Standart ilk defa 01.01.2005 tarihinden sonra başlayan hesap dönemlerinde uygulanmak üzere yayınlanmıștır. Son hâli için bkz. RG 15.01.2019/30656 mükerrer. Aynı düzenleme BOBİ FRS’ye tâbi olan şirketler açısından da geçerlidir (BOBİ FRS m. 9.68).

80 Forstmoser, Meier Hayoz ve Nobel (n 4) §50 N 159. 
ettiği paylar raporlanacaktır. Dolayısıyla şirketin varlık tutarı, iktisap öncesiyle aynı olacaktır. Sadece raporlanan hesaplar farklılaşacaktır. Buna ilişkin bilançonun görünümü - yedek akçe ayrılmaksızın - Tablo 2'deki şekildedir:

Tablo 2:

\section{AKSU GIDA ANONIM ȘİRKTI'NINN 31 ARALIK 2020 TARIHHLI BILLANÇOSU}

VARLIK/AKTIF KAYNAK/PASIF

Dönen Varlık 150.000 TL

Nakit hesab1 $140.000 \mathrm{TL}$

Pay senetleri $10.000 \mathrm{TL}$

Yükümlülükler 0

Özkaynak $150.000 \mathrm{TL}$

Ödenmiș sermaye $100.000 \mathrm{TL}$

Kârdan ayrılan kısıtlanmış yedek $10.000 \mathrm{TL}$

Geçmiş yıllardan aktarılan kâr 40.000 TL

Yeni sistemde ise, her ne sebeple geri alınmış olursa olsun, bir işletmenin özkaynağına dayalı finansal araçların finansal bir varlık olarak dikkate alınmaz (TMS 32 UR36). Bu değişikliğin sebebi, TMS/ TFRS'lerin alındığı Uluslararası Finansal Raporlama Standartlarında ${ }^{81}$ kendi paylarının iktisap edilmesinin pay sahiplerine yapılan katkıların geri ödemesi olduğunu varsaymasıdır ${ }^{82}$. TMS 32 m. 33 uyarınca işletmenin, özkaynağına dayalı finansal araçlarını yeniden edinmesi durumunda, bu araçlar özkaynaktan düşülür. Buna göre, şirketin iktisap ettiği kendi payları, bilançoda özkaynak grubu altında raporlanır. TMS 32 kapsamında işletmenin kendi paylarını alması durumunda, bu paylara ilişkin alım bedelleri özkaynaktan düşülerek “Geri Alınmış Paylar (-)" kaleminde gösterilir ${ }^{83}$. Örneğin Aksu Gıda şirketi, 10.000 TL'lik bir payını, tamamını nakit ödeyerek edinmiştir. Eski sistemde ödenen tutar bedelinde şirketin iktisap ettiği paylar, bilançonun varlık kısmında raporlanıyordu. Dolayısıyla varlık tutarı aynı kalmakla birlikte, raporlanan hesaplar değişiyordu. Yeni sistemde, 10.000 TL'lik nakit para hesabının azaltılmasına rağmen, bilançonun varlık kısmına yeni bir hesap eklenmemektedir. Bu ise, şirketin varlıklarını azaltmaktadır. Bu sebeple, hem bilançonun varlık tarafında pay bedeli ödemesi kadar bir azalma olur hem de geri alınan payların özkaynaktan indirilerek gösterilmeleri nedeniyle bilançonun pasif tarafında küçülme olacaktır ${ }^{84}$. Aksu Gıda şirketinin iktisap ettiği kendi payları, özkaynak grubu altında eksi bir değer olarak raporlanır. Bu paylar, eksi bir değer olarak raporlandığı için, özkaynak tutarı hesaplanırken, “Geri Alınmış Paylar” tutarı, özkaynağı azaltacaktır. Olayımız açısından "Ödenmiş Sermaye (100.000) + Kârdan Ayrılan Kısıtlanmış Yedekler (10.000) + Geçmiş

81 Dünya genelinde farklı ülkelerdeki muhasebe uygulamalarının uyumlaştırılması için gerekli, uluslararası geçerliliğe sahip muhasebe standartlarının oluşturulması amacıyla 29 Haziran 1973’te "Uluslararası Muhasebe Standartları Komitesi-International Accounting Standards Committee (IASC)” kurulmuştur. IASC’ın yeniden yapılandırılmasına yönelik çalışmalar sonucu, tüzügü ve yapısı değiştirilerek 8 Mart 2001'de "Uluslararası Muhasebe Standartları Komitesi Vakfi-International Accounting Standards Committee Foundation (IASCF)” oluşturulmuştur. IASC standart koymak yetkisi de dâhil olmak üzere tüm yetkilerini, IASCF’nin birimlerinden biri olan "Uluslararası Muhasebe Standartları Yönetim Kurulu-International Accounting Standards Board (IASB)"a devretmiștir. IASB, standartlarını "International Financial Reporting Standards (IFRS)” adı altında yayımlamaktadır. İnceleme için bkz. Poroy, Tekinalp ve Çamoğlu, Ortaklıklar II (n 10) 287 vd; Aksu Özkan (n 53) 27-20; Yalçın (n 75) 55.

82 Handschin, 'Aktien' (n 17) 485; Handschin (n 2) Art. 659 N 3; Marlen Stöckli, 'Die neue Bilanzierungsmethode eigener Kapitalanteile und deren (ausbleibender) Einfluss auf Art. 725 Abs. 1 OR' (2016) (2) Quid? Fribourg Law Review 6, 8.

83 FTÖKR 62.

84 Karacan ve Erişir Karacan (n 17) 161. 
Yıllar Kârı (40.000) - Geri Alınmış Paylar (10.000) = Özkaynak (140.000)” olacaktır. Buna göre, yedek akçe ayrılmaksızın - bilançonun yeni hâli Tablo 3’teki gibi olacaktır:

Tablo 3:

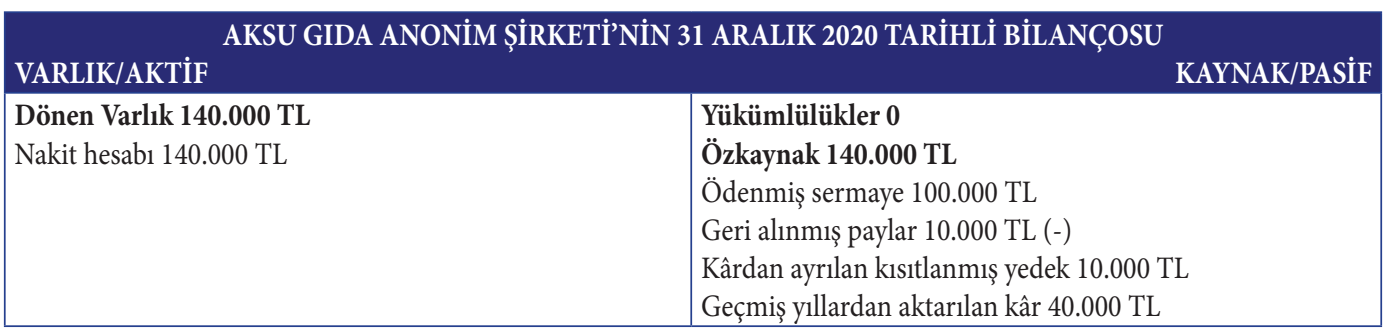

Yavru şirket ana şirketin paylarını edinmişse, bu durumda da payların iktisabı söz konusu olmakla birlikte, bunlar için özel bir raporlama şekli kabul edilmiştir. Buna göre bu paylar, "Geri Alınmış Paylar (-)” kaleminde değil, TMS 32 kapsamında “Karşılıklı İştirak Sermaye Düzeltmesi” kaleminde gösterilir. Bu düzeltme de (-) bir kalem olup, özkaynak tutarını azaltır ${ }^{85}$. Bununla birlikte, yavru şirketin ne şekilde raporlama yapacağına ilişkin bir düzenleme yapılmamıştır. Bu sebeple, yavru şirket tarafından ana şirketin payının iktisabının ne şekilde raporlanacağına ilişkin açık bir düzenleme yapılmalıdır. Bu düzenleme yapılana kadar, kanaatimizce yavru şirket kendi bireysel bilançosundan iktisap etmiş olduğu ana şirketin paylarını finansal varlık olarak raporlayabilir. Zira yavru şirket kendi paylarını iktisap etmediği için, TMS 32 ile öngörülen varlık olarak muhasebeleştirilme yasağı, yavru şirket açısından uygulanamaz.

Özkaynaktan düşürme yönteminde şirketin iktisap ettiği kendi paylarının alışından, satışından, ihracından ya da iptalinden dolayı kâr veya zarara herhangi bir kazanç ya da kayıp yansıtılmaz (TMS 32 m. 33). Buna göre, şirketin iktisap ettiği kendi paylarının değeri, alış fiyatına göre artabilir veya azalabilir. Örneğin itibari değeri 10.000 TL olan ve bu bedel üzerinden satın alınan paylar, 15.000 TLye veya 5.000 TL’ye satılabilir. TMS 32 uyarınca alış fiyatı ile satış fiyatı arasındaki bu fark, şirketin finansal tablo çeşitletinden biri olan kâr veya zarar tablosuna yansıtılamayacaktır. Bu sebeple, şirketin iktisap ettiği kendi paylarına ilişkin değer değişiklikleri şirketin ilgili faaliyet yılındaki dönem net kârını veya zararını etkilemez. Bu sayede, şirketin iktisap ettiği kendi paylarının değerinin kâr olarak dağıtılması engellenmiştir. Zira bilançoda dağıtılabilecek kârın hesaplandığı dönem net kârı hesabı, kâr veya zarar tablosunda raporlanan dönem net kârından aktarılmaktadır. Kanaatimizce bu sakınca sebebiyle, şirketin kendi paylarını alış veya satışının kâr veya zarar tablosunda raporlanması istenmemiştir. Bunun yerine, yine özkaynak grubu altında "Paylara İlişkin Primler/İskontolar" kalemi altında raporlanacaktır ${ }^{86}$.

85 FTÖKR 62.

86 FTÖKR 63; Metemtur Otelcilik ve Turizm İşletmeleri Anonim Şirketi’nin geri alınan paylarının piyasa değeri 1.127.468 TL iken 19.06.2020 tarihinde paylarının tamamını 2.194.958,45 TLye satmıştır. Bu payların geri alımından ve geri alınan payların satışından dolayı kâr ve zarar tablosuna herhangi bir kazanç yahut kayıp yansıtılmamıştır. Geri alınan payların satı̧ıından doğan 832.642 TL kazanç tutarı "Paylara İlişkin Primler/İskontolar" hesabına kaydedilmiştir. Şirketin 01 Ocak - 31 Aralık 2020 dönemine ait konsolide finansal tabloları için bkz. <https://metemtur.com/wp-content/ 
Kanaatimizce şirketin iktisap ettiği payların muhasebeleştirilme şeklinde yapılan değişiklik yerinde bir düzenleme olmuştur. Zira özkaynaklarda raporlanan sermaye kendisiyle değil sadece gerçek varlıklar tarafından karşılanmalıdır ${ }^{87}$. Bunun yanı sıra eski sistemde, şirketin iktisap ettiği kendi payları şirketin varlığı olarak sayıldığı için, payların değerinde gerçekleşen değişimler sebebiyle finansal tablo kullanıcıları kolaylıkla yanıltılabilmektedir ${ }^{88}$. Buna göre, gerçekleşen değişimler kâr veya zarar tablosunda gelir veya gider olarak raporlanacak $^{89}$ ve bu suretle olmayan kâr dağıtılabilecek veya kâr dağıtılması gerekirken dağıtılmayacaktır. Örneğin şirketin bilançosunda 10.000 TL olarak raporlanan payının değeri 15.000 TL’ye yükselmiştir. 5.000 TL'lik bu fark, kâr veya zarar tablosunda bir gelir olarak gösterilecek ve bu da dönem net kâr tutarını etkileyecektir. Keza şirketin iktisap ettiği kendi payların değerindeki değişimler sebebiyle yedek akçenin de değerinde değişim yapılıp yapılmayacağı sorunu ortaya çıkıyordu ${ }^{90}$. Oysa yeni sistemde paylar varlık olmadığı için yedek akçe tutarı açısından da bir tartışma yapılmasına gerek kalmayacaktır. Ayrıca bu yeni yöntem, şirketin kendi paylarının iktisabından elde edilen finansal sonucun daha şeffaf bir sunumunu sağlar ${ }^{91}$. Zira önceki muhasebe yönteminde kendi paylarının iktisabı bilanço açısından etkisi bulunmazken, yeni yöntem bunların küçülmesine yol açar. Bu sayede satın alma maliyetleri tutarında pay sahiplerime yapılan ödemeden kaynaklanan özkaynaktaki daralma daha açık bir şekilde gösterilecektir ${ }^{92}$.

\section{Yedek Akçe Açısından Muhasebeleştirme}

\section{Genel Olarak}

TMS/TFRS'de şirketin kendi paylarının bilançoda ne şekilde yer alacağı belirtilmekle birlikte, yedek akçeler açısından herhangi bir düzenleme bulunmamaktadır. Bununla birlikte, FTÖKR'de ve TFRS Taksonomisinde TTK m. 520/1 uyarınca ayrılan yedek akçelerin, "Kârdan Ayrılmış Kısıtlanmış Yedekler" kaleminde raporlanacağı yer almaktadır ${ }^{93}$. Bunun yanı sıra, BOBİ FRS’de ise açıkça yedek akçe ayrılacağ 1 düzenlenmiştir. Kanaatimizce mevzuat açısından incelendiğinde, TMS/TFRS'ye tâbi olanlar açısından ilgili standartta yedek akçenin bulunmamasının sebebi, bunların öncelikle yayınlanması ve uluslararası standartlardan birebir çeviri olmasıdır. Buna karşılık BOBİ FRS, TMS/ TFRS düzenlemlerinden daha sonra yayınlandı̆̆ 1 için kısmen de olsa TTK düzenlemeleri de dikkate alınmıştır.

uploads/2021/03/Metemtur-31.12.2020-Konsolide-Finansal-Tablolar.pdf > erişim tarihi 21.03.2021.

Handschin (n 2) Art. 659 N 16.

$\mathrm{Bu}$ yöntem, kendi hisse senetlerinin aktivasyonu değil, aynı zamanda şirketin iktisap ettiği kendi paylarının değeri değiştiğinde ortaya çıkan zorlukları da ortadan kaldırır. Bkz. Handschin, 'Aktien' (n 17) 486.

Dekker (n 59) Art. 671a N 5.

Böckli (n 5) $\$ 8$ N 331.

Böckli, Rechnungslegung (n 24) \$ 4 N 469; Imark ve Lipp (n 6) Art. 671a N 3; Haas (n 38) 22.

Haas (n 38) 926; Böckli (n 5) \$ 8 N 335.

FTÖKR 74. Kamuyu Aydınlatma Platformu'na finansal tablo bildiriminde bulunmak zorunda olan işletmeler finansal tablolarını, TFRS Taksonomisine göre hazırlayacaklardır. Taksonomi için bkz. <https://kgk.gov.tr/ DynamicContentDetail/5159/TFRS-Taksonomileri> erişim tarihi 17.09.2020. 
Yukarıda verilen örnekten devam edilirse, şirketin iktisap ettiği kendi payları için iktisap değeri olan 10.000 TL tutarında yedek akçe ayırması gerekir. Bu, şirketin geçmiş yıllar kârından karşılanacaktır. Buna göre, geçmiş yıllar kârı 30.000 TL’ye düşecek ve "Kârdan Ayrılan Kısıtlanmış Yedek" hesabının tutarı, 20.000 TL’ye çıkacaktır. Bilançonun dipnotlarında da bu hesaba ilişkin kısımda, şirketin iktisap ettiği kendi payları için 10.000 TL tutarında yedek akçe ayrıldığı açıklanacaktır. Buna ilişkin bilanço görünümü Tablo 4 'teki şekilde olacaktır ${ }^{94}$ :

Tablo 4:

\begin{tabular}{|c|c|}
\hline \multicolumn{2}{|c|}{ AKSU GIDA ANONIM ŞİRKETİNIN 31 ARALIK 2020 TARIHLİ BİLANÇOSU } \\
\hline VARLIK/AKTIF & KAYNAK/PASIF \\
\hline $\begin{array}{l}\text { Dönen Varlık } 140.000 \text { TL } \\
\text { Nakit hesab1 } 140.000 \text { TL }\end{array}$ & $\begin{array}{l}\text { Yükümlülükler } 0 \\
\text { Özkaynak } 140.000 \mathrm{TL} \\
\text { Ödenmiş sermaye } 100.000 \mathrm{TL} \\
\text { Geri alınmış paylar } 10.000 \mathrm{TL}(-) \\
\text { Kârdan ayrılan kısıtlanmış yedek } 20.000 \mathrm{TL} \\
\text { - Yasal yedekler 10.000 TL } \\
\text { - Geri alınan paylara ilişkin yedek } 10.000 \mathrm{TL} \\
\text { Geçmiş yıllar kârı 30.000 TL }\end{array}$ \\
\hline
\end{tabular}

Yukarıdaki bilanço incelendiğinde görüldüğü üzere, şirketin iktisap ettiği kendi payları için yedek akçe ayırması bilançonun özkaynak tutarında herhangi bir değişikliğe yol açmaz. Sadece özkaynak grubunda raporlanan serbest özkaynağı, şirketin bağlı malvarlı̆̆ı hâline getirir. Bununla birlikte, öğretide bir görüş bilançoda aynı tutarın hem kendi payları için yedek akçe olarak gösterilmesi hem de eksi kalem olarak kaydedilmesinin mümkün olmadı̆̆ 1 yönündedir ${ }^{95}$. Diğer bir görüş ise teorik olarak bir negatif kalem ile bir (pozitif) yedek akçenin aynı anda açıklanması mümkün olacağı yönündedir ${ }^{96}$. Kanaatimizce de bilançonun pasifinde hem şirketin iktisap ettiği kendi paylarının hem de bunlar için ayrılan yedeğin raporlanması mümkündür. Zira şirketin kendi payları için ayırdığg yedek akçe, şirketin serbet özkaynağının bağlı özkaynak hâline getirilmesi olduğu için muhasebeleştirme açısından bir sorun oluşturmaz. Buna karşılık, kanaatimizce burada değerlendirilmesi gereken konu şirketin kendi paylarına ilişkin yeni raporlama şekli sebebiyle şirketin kendi paylarına ilişkin yedek akçe ayırmasının gerekip gerekmeyeceğidir.

\section{Yeni Sistemde Yedek Akçe Ayrılmasının Gerekliliğinin Değerlendirilmesi}

Kanaatimizce şirketin kendi iktisap ettiği payların muhasebeleştirme şeklinin değişiminden sonra, bu paylar için yedek akçe ayırmaya gerek yoktur ${ }^{97}$. Zira eski sistemde şirketin iktisap ettiği

94 Benzer şekilde uygulamadan örnek için bkz. İttifak Holding Anonim Şirketi ve Bağlı Ortaklıkları’nın 31 Aralık 2019 tarihinde sona eren hesap dönemine ait konsolide finansal tabloları için bkz. <https:/www.ittifak.com.tr/App_Assets/ Genel/Finans/20379/2019-12-hesap-donemine-ait-konsolide-finansal-tabl.pdf> erişim tarihi 20.03.2021.

95 Glanzmann (n 38) 268.

96 Haas (n 38) 922.

97 Aynı yönde bkz. Türk (n 3) 286. 
kendi payları için ayrılan yedek akçenin gördüğü işlev, yeni sistemde sadece payların özkaynaktan düşülmesi ile sağlanmaktadır. Buna göre eski sistemde iktisap edilen paylar, şirketin varlığı olarak raporlandığı için bilançoda şirketin bu tutarda malvarlığı olduğu görünmekteydi. Bu payların değerinde yaşanacak değişimlerin taşıdığı riskler sebebiyle payların iktisap değeri kadar yedek akçe bilançonun pasifinde ayrılmaktaydı. Bu sayede, aktifleştirilen paylar nötr hâle getirilerek şirketin, iktisap değeri tutarındaki özkaynağı pay sahiplerine dağıtmaması garanti altına alınıyordu ${ }^{98}$. Buna karşıllk yeni sistemde, iktisap edilen paylar aktifte yer almayıp pasifte özkaynağ olarak raporlanmaktadır. Dolayısıyla özkaynaktan düşürme yöntemi, şirketin iktisap ettiği kendi payları için ayrılan kanuni yedek akçe de olduğu gibi, şirketin dağıtım potansiyelinde bir azalmaya neden olur ve böylece sermayeyi korumaya hizmet eder ${ }^{99}$. Bunun yanı sıra, böyle bir değişiklik ödenen pay bedeli ölçüsünde serbest yedek akçenin pay sahiplerine kâr olarak dağıtılmasını önlemek bakımından bir sakınca yaratmaz. Zira sonuçta bu hâlde de serbest yedek akçeler tutarı ödenen pay bedeli ölçüsünde azalır ${ }^{100}$. Dolayısıyla bu durum, yedek akçe ayrılmasıyla aynı işlevi sağlamakta ve yedek akçe ayrılmasının amacını ortadan kaldırmaktadır ${ }^{101}$. Aksi takdirde, özkaynak çifte bloke edilmiş olacaktır ${ }^{102}$.

Bunun yanı sıra şirketin iktisap ettiği kendi payları için yedek akçe ayrılmasını öngören TTK m. 520'nin mehazını oluşturan OR Art. 671a'da yaşanan değişiklikler de, bu görüşümüzü desteklemektedir. Eski sistemde şirketin iktisap ettiği kendi payları varlık olarak bilançonun aktifinde muhasebeleştiriliyordu ${ }^{103}$. Buna karşı bir kalem olarak, bilançonun pasif tarafında iktisap değerine karşılık gelen bir tutarı yedek akçe olarak gösteriyordu (OR Art. 659a/2). Yeni muhasebe kanunun getirilmesi, şirketin iktisap ettiği kendi paylarının muhasebeleştirilmesi kavramında bir değişikliğe yol açtı ${ }^{104}$. Buna göre, bu paylar artık bilançonun aktifinde varlık olarak kaydedilmeyecek; ancak özkaynakta "negatif kalem" olarak raporlanacaktır [OR Art. 959b/II(3e)]. Bununla birlikte, şirketin, iktisap edilen paylar için ayrı bir yedek akçe oluşturması zorunluluğunu düzenleyen OR Art. 659a/2 ve kendi payları için ayrılan yedek akçenin, bu paylar devredilmedikçe veya yok edilmedikçe çözülemeyeceğini düzenleyen OR Art. 671a hâlâ yürürlüktedir ${ }^{105}$. Öğretide OR 659a/2

98 Sevi, Pay (n 15) 87; Forstmoser, Meier Hayoz ve Nobel (n 4) §50 N 41.

99 Böckli, Rechnungslegung (n 24) § 4 N 469; Haas (n 38) 922; Glanzmann, 'Bilanzierung' (n 38) 285-286; Stöckli (n 82) 8; Lorenz Lipp, 'Art. 959a' iç Vito Roberto ve Hans Rudolf Trüeb (edr), CHK - Handkommentar zum Schweizer Privatrecht GmbH, Genossenschaft, Handelsregister und Wertpapiere - Bucheffektengesetz (3. Bas1, Schulthess 2016) Art. 959a N 58a. Özkaynakta eksi tutarın oluşumu, özkaynak dağıtma olasılığını azaltır ve şirketin iktisap ettiği kendi payları için ayrı bir yedek akçe yaratma zorunluluğunun yerine geçer. Bkz. Handschin (n 2) Art. 659 N 20.

100 Türk (n 3) 286; Handschin 'Aktien' (n 17) 486; Lipp (n 99) Art. 959a N 58a; Glanzmann, 'Bilanzierung' (n 27) 285-286.

101 Haas (n 38) 922; Handschin 'Aktien' (n 17) 486.

102 Neuhaus ve Balkanyi (n 10) Art. 671a N 10a; Stöckli (n 82) 9; Handschin 'Aktien’ (n 17$) 486$.

103 Forstmoser, Meier Hayoz ve Nobel (n 4) $\$ 50$ N 159; Böckli (n 5) $\$ 8$ N 323; Glanzmann, 'Bilanzierung' (n 27) 285; Handschin, 'Aktien' (n 17) 485.

104 Imark ve Lipp (n 6) Art. 671a N 3; Haas (n 38) 922; Glanzmann (n 38) 267; Böckli (n 5) $\$ 8$ N 271, 335; Böckli, Rechnungslegung (n 22) \$4 N 506; Handschin, 'Aktien' (n 17) 485.

105 İsviçre Borçlar Kanununun değişikliğine yönelik taslak metinde, OR 671a yürürlükten kaldırılmıştır. Taslak metninin son hâli için bkz. <https://unternehmerforum.ch/wp-content/uploads/2020/09/2241-Aktienrecht-ObligationenrechtStand-19.06.2020> erişim tarihi 07.03.2021. Kanun değişikliğinin daha önceki taslakları için bkz. <https://www. parlament.ch/en/ratsbetrieb/suche-curia-vista/geschaeft?AffairId=20160077> erişim tarihi 07.03.2021. 
ve 671a hükümleri henüz resmi olarak yürürlükten kaldırılmadığı sürece, yeni muhasebe kanunu ile mevcut şirketler kanunu arasında bir tutarsızlık olduğu ifade edilmiştir. Buna göre, muhasebe kanunu ile anonim şirketler hukuku arasındaki mevcut çelişki, muhasebe kanununun daha yeni düzenlemesi lehine "lex posterior derogat legi priori” (yeni norm eski normdan önceliklidir) ilkesine göre çözülmelidir ${ }^{106}$. Keza Alman Hukuku’nda da şirketin iktisap ettiği kendi paylarının muhasebeleştirilme şeklinin değiştirilmesinden ${ }^{107}$ sonra, öğretide bu değişikliğin yedek akçe oluşturma yükümlülüğünü ortadan kaldırdığı ifade edilmektedir ${ }^{108}$. Zira şirketin kendi payları bilançonun aktifinde yer almadığı için bu değerin pasifte oluşturan yedek akçe ile nötrleştirilmesine gerek kalmamıştır ${ }^{109}$.

Son olarak bu sistem değişikliği olmaksızın da, bu paylar için ayrılan yedek akçenin düzenlenme amacını tam olarak sağlayamaması buna ilişkin yedek akçenin kaldırılması gerektiği görüşümüzü desteklemektedir. Buna göre şirketin iktisap ettiği kendi payları açısından bu paylar için ayrılan yedek akçenin yalnızca etkin özkaynak üzerinde dağıtımı engelleyici bir etkisi vardır, ancak karşılık gelen özkaynağın kendisini yaratamaz. Varlıkların uzun vadede küçülmesi durumunda, bilançoda muhasebeleştirilebilen mevcut özkaynak, bloke bir alt hesaba kaydedilmiş olmasına bakılmaksızın aynı ölçüde kaybolur ${ }^{110}$. Dolayısıyla şirketin iktisap ettiği paylar için ayrılan yedek akçe, şirketin finansal durumunun kötüleşmesi durumunda sadece kâğıt üzerinde bir değerden ibaret olacak; ancak şirketin malvarlığında bu tutarda varlık bulunmayacaktır. Bu sebeple, şirketin iktisap ettiği kendi payları için yedek akçe ayrılmasının şirketi koruyucu bir etkisi olmayacaktır.

\section{Sonuç}

TTK m. 520/1 uyarınca kendi paylarını iktisap eden anonim şirket, payların iktisap değeri tutarında yedek akçe ayırmakla yükümlüdür. Bu düzenleme ile payların iktisap bedeli kadar bir tutar şirketin serbest özkaynağından çıkarılacak ve şirketin iktisap ettiği kendi payları için ayrılan yedek akçe

106 Haas (n 38) 922; Imark ve Lipp (n 6) Art. 671a N 6; Neuhaus ve Balkanyi (n 10) Art. 671a N 10a; Trüeb (n 4) Art. 659a N 12; Stöckli (n 82) 8; Forstmoser, Meier Hayoz ve Nobel (n 4) $\$ 50$ N 159; Handschin, 'Aktien’ (n 17) 485-486; Lipp (n 99) Art. 959a N 56.

107 Buna göre, HGB $\$ 272 / 2$ 'nin ilk hâlinde şirketin iktisap ettiği payların bilançoda varlık olarak muhasebeleştirilmesi; 272/4'te ise bunun için ayrılacak yedek akçe düzenlenmekteydi. Bunun yerine, yeni sistemde şirketin iktisap ettiği paylar bilançonun özkaynak grubunda taahhüt edilen sermaye tutarından indirilerek gösterilmektedir (HGB $\$$ 272/2). HGB $\$ 272 / 4$ ’te ise, sadece hâkim veya çoğunluk paya sahip şirkette pay edinimi için yedek akçe ayrılması yükümlülüğüne yer verilmiştir. Bu değişiklik Alman Ticaret Kanununun bilançoya ait hükümlerinin 2009 yılında Gesetz zur Modernisierung des Bilanzrechts (Bilanzrechtsmodernisierungsgesetz - BilMoG) vom 15. Mai 2009 “Bilanço Hukukukunun Modernleştirilmesi Hakkında Kanun” ile yapılmıştır. Kanun metni için bkz. https://www.bgbl.de/ xaver/bgbl/start.xav?startbk=Bundesanzeiger_BGBl\&jumpTo=bgbl109s 1102.pdf\#_bgbl__\%2F\%2F*\%5B\%40attr_ id\%3D\%27bgbl109s1102.pdf\%27\%5D_161.521.4609842> erişim tarihi 08.03.2021.

108 Grigoleit ve Rachlitz (n 5) \$71 N 137; Hüffer ve Koch (n 31) \$71 N 21a; Paefgen (n 21) \$71 N 40; Pöschke (n 34) \$272 N 63.

109 Bununla birlikte şirketin kendi paylarını iktisabının düzenlendiği AktG $\$ 71 / 2$ 'de şirketin iktisap ettiği paylar için yedek akçe ayırmasına ilişkin düzenleme hala yürürlüktedir. Bu sebeple öğretide yönetim kurulunun, payları iktisap ederken varsayımsal olarak yedek akçe ayırmaya yetecek kadar serbest malvarlığının olup olmadığını kontrol etmesi gerektiği ifade edilmektedir. Bkz. Hüffer ve Koch (n 31) § 71 N 21a; Pöschke (n 34) § 272 N 63.

110 Böckli (n 5) \$ 4 N 246. 
kalemine aktarılacaktır. Bu sayede, şirketin kendi paylarını iktisap için harcadığı tutar kadar varlığın, genel kurul tarafından kullanılması ve özellikle bunun pay sahiplerine dağıtılması engellenir.

Şirketin iktisap ettiği paylar için yedek akçe ayırma yükümlülüğü şirketin kendi payını iktisap etmesiyle doğar. Bununla birlikte, ana şirket yavru şirket ilişkisi olduğunda kimin yedek akçe ayırması gerektiğine ilişkin TTK'de bir düzenleme bulunmamaktadır. Kanaatimizce bu durumda, ana şirket yedek akçe ayırmakla yükümlü olmalıdır. Bu yükümlülüğe aykırı davranış, şirketin kendi paylarını iktisabını geçersiz kılmaz. Buna karşılık, şirketin bilançosunun geçersiz olmasına ve yönetim kurulunun sorumluluğuna gidilmesine sebep olabilir.

KGK'nin düzenlemeleriyle şirketin iktisap ettiği kendi paylarının muhasebeleştirilme şekli değiştirilmiştir (TMS $32 \mathrm{~m}$. 33). Buna göre, şirketin iktisap ettiği kendi payları şirketin varlı̆̆ olarak bilançonun aktifinde raporlanmayacaktır. Bunun yerine, bu paylar özkaynaktan düşülür. Bu değişiklik sebebiyle kanaatimizce bu paylar için yedek akçe ayırmaya gerek yoktur Zira eski sistemde şirketin iktisap ettiği kendi payları için ayrılan yedek akçenin gördüğü işlev, yeni sistemde sadece payların özkaynaktan düşülmesi ile sağlanır.

\section{KAYNAKÇA}

Aksu Özkan R, Finansal Tabloların Tutulması ve Hukuksal Sonuçları (On İki Levha 2019)

Ayan Ö, 'Anonim Şirketin Genel Kuru Kararı ile Kendi Paylarını İktisap etmesi veya Rehin Almasının Koşulları' (2013) XVII(1-2) Gazi Üniversitesi Hukuk Fakültesi Dergisi 185-228

Aydın A, Anonim Ortaklı̆̆ın Kendi Paylarını Edinmesi (Vedat 2008)

Bahtiyar M, Ortaklıklar Hukuku (14. Bası, Beta 2020)

Baş K, 'Türk Ticaret Kanunu Uyarınca Anonim Şirketin Paylarının Yavru Şirketi Tarafından İktisap Edilmesi: Sorunlar, Saptamalar ve Öneriler', iç Murat Alışkan, Bilge Utkan Mersin, Sinan Sarıkaya (edr), Sermaye Şirketleri Hukukunda Güncel Gelişmeler Sempozyumu (Tebliğler-Tartışmalar, 19 Haziran 2019) (On İki Levha 2020) 119-166

Bayazıtlı E, Çelik O ve Gürdal K, Genel Muhasebe (Siyasal 2016)

Böckli P, Schweizer Aktienrecht (4. Bası, Schulthess 2009)

Böckli P, OR-Rechnungslegung (2. Bas1, Schulthess 2019) (Rechnungslegung)

Dekker S, iç Jeannette K. Wibmer (ed), Aktienrecht Kommentar Aktiengesellschaft, Rechnungslegungsrecht, VegüV, GeBüV, VASR (Orell Füssli 2016)

Doğan BF, Der Erwerb eigener Aktien im deutschen und türkischen Recht im Hinblick auf europäisches Recht (Kovac 2004)

Ertaş FC ve Karaca S, 'Kâr Dağıtımının İlânı ve Gerçekleşmesi Arasında Geçen Sürenin Firma Değerine Etkisi’ (2010) (47) Muhasebe ve Finansman Dergisi 58-68

Forstmoser P, Meier Hayoz A ve Nobel P, Schweizerisches Aktienrecht (2. Bası, Stämpfli Verlag 1996)

Glanzmann L, 'Das neue Rechnungslegungsrecht' iç Peter V Kunz, Oliver Arter ve Florian Jörg (edr), Entwicklungen im Gesellschaftsrecht VIII (Stämpfli 2013) 251-289

Glanzmann L, 'Die Bilanzierung des Eigenkapitals im Einzelabschluss von Kapitalgesellschaften' Schweizerische Zeitschrift für Wirtschafts - und Finanzmarktrecht, 2017 <https://www.alexandria.unisg.ch/257247/1/ SZW\%20Bilanzierung\%20des\%20EK.pdf> erişim tarihi 01.12.2020 (Bilanzierung) 
Gökçen G, Genel Muhasebe (Beta 2015)

Gökgöz A, 'Hisse Senedi Geri Alımı ve Muhasebesi' (2014) (2) Muhasebe ve Vergi Uygulamaları Dergisi 1-14 Gökgöz A, Genel Muhasebe (Ekin 2015) (Genel)

Grigoleit HC ve Rachlitz R, iç Hans Christoph Grigoleit (ed), Aktiengesetz Kommentar (2. Bası, C.H. Beck 2020)

Haas C, 'Eigene Aktien und Kapitalverlust' (2013) (12) Der Schweizer Treuhänder 921-927

Handschin L, 'Eigene Aktien im Konzern' (2013) (8) Der Schweizer Treuhänder 485-489 ('Aktien’)

Handschin L (ed), Zürcher Kommentar Die Aktiengesellschaft, Allgemeine Bestimmungen, Art. 620-659b OR (2. Bası, Schulthess 2016)

Hüffer U ve Koch J, iç Uwe Hüffer ve Jens Koch (edr), Aktiengesetz (15. Bası, C.H. Beck 2021)

Imark L ve Lipp L, 'Art. 671-671a' OR iç Vito Riberto ve Hans Rudolf Trüeb (edr), Handkommentar zum Schweizer Privatrecht, Personengesellschaften und Aktiengesellschaft - Vergütungsverordnung, Art. 530771 (3. Bas1, Schulthess 2016)

Karacan Aİ ve Erişir Karacan E, Halka Açık Şirketlerin Kendi Paylarını Geri Alımı (Legal 2015)

Karayalçın Y, Muhasebe Hukuku (2. Bası, Banka ve Ticaret Hukuku Araştırma Enstitüsü 1988)

Kropff B, iç Joachim Hennrichs, Detlef Kleindiek ve Christoph Watrin (edr), Münchener Kommentar zum Bilanzrecht, Band 2, \$\$ 238-342e HGB (C.H. Beck 2013)

Küçüksavaş N, Finansal Muhasebe (14. Bası, Beta 2016)

Lenz C ve von Planta A, 'Art. 659-659b’ iç Heinrich Honsell, Nedim Peter Vogt ve Rolf Watter (edr), Basler Kommentar Obligationenrecht II Art. 530-964 OR (5. Bas1, Helbing Lichtenhahn 2016)

Lipp L, 'Art. 959a' iç Vito Roberto ve Hans Rudolf Trüeb (edr), CHK - Handkommentar zum Schweizer Privatrecht $\mathrm{GmbH}$, Genossenschaft, Handelsregister und Wertpapiere - Bucheffektengesetz (3. Bas1, Schulthess 2016)

Neuhaus MR ve Balkanyi P, 'Art. 671-671a' iç Heinrich Honsell, Nedim Peter Vogt ve Rolf Watter (edr), Basler Kommentar Obligationenrecht II Art. 530-964 OR (5. Bas1, Helbing Lichtenhahn 2016)

Okutan Nilsson G, 'Anonim Şirketlerin Kendi Hisselerini İktisabı Bağlamında Finansal Yardım Yasağı', Anonim Şirketler ve Sermaye Piyasası Hukukunda Güncel Gelişmeler Türk - Alman Uluslararası Sempozyumu (İstanbul Borsas1 2011) 90-100

Otlu F, Bekçi İ ve Özlem Karataş NÖ, ‘TTK’ya göre Anonim Şirketlerin Kendi Paylarını İktisap Etmesi ve Muhasebeleştirmesi’ (2014) 4(1) Çankırı Karatekin Üniversitesi İktisadi ve İdari Bilimler Fakültesi Dergisi 283-298

Özdamar M, Anonim Ortaklıkların Kendi Paylarını İktisap Etmesi (TTK md. 329) (Yetkin 2005)

Paefgen WG, iç Martin Henssler ve Lutz Strohn (edr), Gesellschaftsrechts (5. Bası, C.H. Beck 2021)

Poroy R, Tekinalp Ü ve Çamoğlu E, Ortaklıklar Hukuku I (14. Bası, Vedat 2019)

Poroy R, Tekinalp Ü ve Çamoğlu E, Ortaklıklar Hukuku II (14. Bası, Vedat 2019) (Ortaklıklar II)

Pöschke M, iç Martin Henssler, Carsten Herresthal ve Marian Paschke (edr), beck-online.Grosskommentar zum Bilanzrecht, $\$ \$ 238$ - 342e Handelsgesetzbuch (C.H. Beck 2020)

Pulaşlı H, Şirketler Hukuku Şerhi C. 3 (3. Bası, Adalet 2018)

Sevi AM, 'Anonim Ortaklı̆̆ın Kendi Payını Devralması Üzerine Bir İnceleme' (2003) 22(1) Banka ve Ticaret Hukuku Dergisi 239-267

Sevi AM, Anonim Ortaklıkta Payın Devri (4. Bası, Seçkin 2018) (Pay)

Sevilengül O, Genel Muhasebe (18. Bas1, Gazi 2016)

Sözer C, Anonim Şirketlerin Kendi Paylarını İktisabının Vergisel Sonuçları (2. Bası, İstanbul 2014)

Stöckli M, 'Die neue Bilanzierungsmethode eigener Kapitalanteile und deren (ausbleibender) Einfluss auf Art. 725 Abs. 1 OR' (2016) (2) Quid? Fribourg Law Review 6-11 
Şener OH, Teorik ve Uygulamalı Ortaklıklar Hukuku (4. Bası, Seçkin 2019)

Şener OH, Yargıtay Kararları Işı̆̆ııda Limited Ortaklıklar Hukuku (Seçkin 2017)

Tanış VN, Genel Muhasebe İlkeler ve Uygulamalar (9. Bası, Karahan 2016)

Tekinalp Ü, Anonim Ortaklı̆̆ın Bilançosu ve Yedek Akçeleri (2. Bası, Fakülteler 1979)

Tekinalp Ü, Sermaye Ortakliklarının Yeni Hukuku (5. Bası, Vedat 2020) (Sermaye)

Trüeb HR, 'Art. 659 - 659a' iç Vito Roberto ve Hans Rudolf Trüeb (edr), Handkommentar zum Schweizer Privatrecht, Personengesellschaften und Aktiengesellschaft - Vergütungsverordnung, Art. 530-771 OR VegüV (3. Bas1, Schulthess 2016)

Turan G, Anonim Ortaklikların Kendi Paylarını İktisabının Genel Esasları (Yetkin 2018)

Türk A, Yeni Türk Ticaret Kanunu ve Sermaye Piyasası Mevzuatına Göre Anonim Ortaklı̆̆ın Kendi Paylarını Edinmesi (Adalet 2016)

Uysal T ve Şenlik M, Genel Muhasebe (Seçkin 2016)

Üçışık G ve Çelik A, Anonim Ortaklıkta Finansal Tablolar Yedek Akçeler ve Kâr Dağıtımı (On İki Levha 2018)

Winnefeld R, Bilanz-Handbuch (5. Bası, C.H. Beck 2015)

Yalçın E, Uluslararası Finansal Raporlama (Seçkin 2015)

Yanlı V, 'Anonim Şirketlerde Kâr Dağıtımı' (2014) XXX(1) Banka ve Ticaret Hukuku Dergisi 5-32 